University of Arkansas at Little Rock William H. Bowen School of Law Bowen Law Repository: Scholarship \& Archives

Faculty Scholarship

2017

\title{
The Bankruptcy of Refusing to Hire Persons Who Have Filed Bankruptcy
}

Terrence Cain

University of Arkansas at Little Rock William H. Bowen School of Law, txcain@ualr.edu

Follow this and additional works at: https://lawrepository.ualr.edu/faculty_scholarship

Part of the Bankruptcy Law Commons, and the Labor and Employment Law Commons

\section{Recommended Citation}

Terrence Cain, The Bankruptcy of Refusing to Hire Persons Who Have Filed Bankruptcy, 91 Am. Bankr. L.J. 657, 657 (2017).

This Article is brought to you for free and open access by Bowen Law Repository: Scholarship \& Archives. It has been accepted for inclusion in Faculty Scholarship by an authorized administrator of Bowen Law Repository: Scholarship \& Archives. For more information, please contact mmserfass@ualr.edu. 


\title{
The Bankruptcy of Refusing to Hire Persons Who Have Filed Bankruptcy
}

\author{
by
}

Terrence Cain*

\section{ABSTRACT}

In 1978, Congress made it illegal for government employers to deny employment to, terminate the employment of, or discriminate with respect to employment against a person who has filed bankruptcy. In 1984, Congress extended this prohibition to private employers by making it illegal for such employers to terminate the employment of, or discriminate with respect to employment against a person who has filed bankruptcy. Under the law as it currently exists, private employers can refuse to hire a person who has filed bankruptcy solely because that person has filed for bankruptcy. Meanwhile, employers have substantially increased their use of credit history checks as a pre-employment screening device. Credit history checks will disclose bankruptcy filings, and because blacks and Latinos are overrepresented among bankruptcy filers, these groups are disproportionately affected by bankruptcy discrimination. This disparate impact probably violates Title VII of the Civil Rights Act of 1964. Moreover, there is scant empirical support for the proposition that creditworthiness is a reliable proxy for workplace performance or employee trustworthiness.

Relying on bankruptcy status simpliciter is antithetical to a core purpose of the bankruptcy system, which is to give debtors a fresh start. Employers' prerogatives to operate according to whatever employment policies and practices they want should be balanced against employees' and potential employ. ees' right to participate in the labor market in an environment free of

*Professor of Law, University of Arkansas at Little Rock William H. Bowen School of Law. The law school where I am honored and privileged to teach provided a research grant in order for me to write this Article. I am very grateful to Professor Michael D. Sousa of the University of Denver Sturm College of Law, who served as my editor for this Article and showed me tremendous patience and courtesy while doing so. Any errors are solely my responsibility. Finally, I am grateful to every author whose work I cited. All of you have made valuable contributions to the subject of balancing an employer's prerogative to hire or refuse to hire a person on any terms that it sees fit with the employee's right to work or attempt to work in an environment that is free of irrational discrimination. I bope this Article does likewise. 
irrational discrimination. It is irrational to deny employment to a person who is or was a debtor if the person is otherwise qualified, and the job can be successfully performed regardless of bankruptcy status. To allow such discrimination makes the bankruptcy system's promise of a fresh start illusory.

\section{INTRODUCTION.}

One of the purposes of the Bankruptcy Code is to give those who seek its protections a "fresh start" from the financial problems that caused them to file bankruptcy in the first place. ${ }^{1}$ In order to effectuate the fresh start principle of the Bankruptcy Code, Congress enacted 11 U.S.C. $\S 525$ on November 6, $1978 .{ }^{2}$ Section 525 prohibits government employers from denying employ. ment to, terminating the employment of, or discriminating with respect to employment against a person who is or has been a debtor, or who is or has been associated with a debtor. ${ }^{3}$ On July 10, 1984, Congress extended this non-discrimination principle to private employers by enacting 11 U.S.C. $\S 525(\mathrm{~b})$, which prohibits private employers from terminating the employ. ment of, or discriminating with respect to employment against a person who is or has been a debtor, or who is or has been associated with a debtor. 4

Under $\S 525$, government employers are expressly prohibited from "denying employment to" persons who have filed bankruptcy or who are currently in a bankruptcy proceeding, ${ }^{5}$ but private employers are not. ${ }^{6}$ Despite the absence of an express prohibition on private employers refusing to hire a debtor, an issue has arisen in the courts on the question of whether private employers, like their government counterparts, are prohibited from "denying employment to" a person because that person is or has been in bankruptcy, and every court that has addressed the question except one has held that $\S 525$ (b) does not prohibit private employers from refusing to hire a person

\footnotetext{
${ }^{1}$ Perez v. Campbell, 402 U.S. 637, 648 (1971) (quoting Local Loan Co. v. Hunt, 292 U.S. 234, 244 (1934)).

${ }^{2}$ Act of Nov. 6, 1978, Pub. L. No. 95-598, 92 Stat. 2549-2688 (1978); S. Rep. No. 95-989, at 1 (1978), reprinted in 1978 U.S.C.C.A.N. 5787; H.R. Rep. No. 95.595, at 3.5 (1977), reprinted in 1978 U.S.C.C.A.N. 5964-67. The law went into effect on October 1, 1979.

${ }^{3}$ Act of Nov. 6, 1978, Pub. L. No. 95,598, Title I, § 525, 92 Stat. 2549, 2593 (1978) (codified as 11 U.S.C. $\$ 525$ ).

${ }^{4}$ Bankruptcy Amendments and Federal Judgeship Act of 1984, Pub. L. No. 98-353, Title III, $\$ 309,98$ Stat. 333, 352, 354-55 (1984). Section 525(b) became effective for cases filed on or after October 9, 1984 Bankruptcy Amendments and Federal Judgeship Act of 1984, Pub. L. No. 98-353, Title III, § 553(a), 98 Stat. 333, 352, 392 (1984); Madison Madison Int'l of Ill., P.C. v. Matra, S.A. (In re Madison Madison Int"l of I11., P.C.), 77 B.R. 678,680 (Bankr. E.D. Wis. 1987). This legislation also renumbered the original $§ 525$ as $§ 525(\mathrm{a})$. Bankruptcy Amendments and Federal Judgeship Act of 1984, Pub. L. No. 98-353, Title III, $\S 309,98$ Stat. $333,352,354-55$ (1984).

${ }^{5} 11$ U.S.C. $\$ 525(\mathrm{a})$.

${ }^{6} 11$ U.S.C. $\$ 525(\mathrm{~b})$.
} 
who is or has been a debtor. ${ }^{7}$ Alongside judicial decisions ratifying private employers' right to refuse to hire debtors, is the widespread practice of em. ployers using credit history checks as a pre-employment screening device. ${ }^{8}$ Some of the reasons employers give for running credit history checks on applicants for employment include reducing the likelihood of theft, fraud, embezzlement, and other criminal activity, managing liability for negligent hiring, assessing the overall trustworthiness of applicants, and compliance with state laws that mandate background checks. ${ }^{9}$ There is a debate among

\footnotetext{
7Compare Myers v. TooJay’s Mgmt. Corp., 640 F.3d 1278, 1283-87 (11th Cir. 2011) (\$ 525(b) does not cover a refusal to hire); Burnett v. Stewart Title, Inc. (In re Burnett), 635 F.3d 169, 171.74 (5th Cir. 2011) (same); Rea v. Federated Investors, 627 F.3d 937, 940-41 (3d Cir. 2010) (same); Fiorani v. CACI, 192 B.R. 401, 404-07 (E.D. Va. 1996) (same); Pastore v. Medford Sav. Bank, 186 B.R. 553, 554-55 (D. Mass. 1995) (same); Martin v. Am. Family Mut. Ins. Co. (In re Martin), Adversary No. 07-7067, Bankruptcy No. 06-41010, 2007 WL 2893431, at *1.5 (Bankr. D. Kan. Sept. 28, 2007) (same); Stinson v. BB \& T Inv. Servs., Inc. (In re Stinson), 285 B.R. 239, 241-50 (Bankr. W.D. Va. 2002) (same), and In re Hardy, 209 B.R. 371, 374-79 (Bankr. E.D. Va. 1997) (\$ 525(b) applies only if the debtor is an employee of the defendant, and a person who has not been hired is not an employee); In re Bobbitt, 174 B.R. 548, 552 (Bankr. N.D. Cal. 1993) (same); In re Briggs, 143 B.R. 438, $443-45$ (Bankr. E.D. Mich. 1992) (same); In re Henry, 129 B.R. 75, 78 (Bankr. E.D. Va. 1991) (same); Spaulding v. Citizens Fed. Sav. \& Loan Ass'n of Dayton (In re Spaulding), 116 B.R. 567, 569, 571-73 (Bankr. S.D. Ohio 1990) (same); In re Hopkins, 81 B.R. 491, 494 (Bankr. W.D. Ark. 1987) (same); Madison Madison Int'l of Ill., P.C. v. Matra, S.A. (In re Madison Madison Int'l of Ill., P.C.), 77 B.R. 678, 680, 682 (Bankr. E.D. Wis. 1987) (same), with Leary v. Warnaco, Inc., 251 B.R. 656, 658.59 (S.D.N.Y. 2000) (\$525(b) probibits private employers from refusing to hire a debtor just as $\$ 525(\mathrm{a})$ prohibits government employers from refusing to hire a debtor), and Comeaux v. Brown \& Williamson Tobacco Co., 915 F.2d 1264, 1268.69 (9th Cir. 1990) (The court affirmed an order granting summary judgment in favor of the employer because the plaintiff did not prove that the employer's sole reason for refusing to hire her was its knowledge of her bankruptcy filing. This suggests that had the plaintiff proved that the employer's sole reason for refusing to hire her was its knowledge of her bankruptcy, the court would have reversed the order granting the employer's motion for summary judgment on the $\$ 525$ (b) refusal to hire issue.).

${ }^{8}$ Roberto Concepción, Jr., Pre-Employment Credit Checks: Effectuating Disparate Impact on Racial Minorities Under the Guise of Job-Relatedness and Business Necessity, 12 SCHOLAR 523, 530.35 (2010) (in $2003,35 \%$ of employers used credit checks compared with $19 \%$ in 1996; in 2008,38.7\% of retailers used credit history checks as a preemployment screening measure, and estimated that in 2009 retailers' reliance on credit history checks increased by 7.6\%); Beverley Earle, Gerald Madek \& David Missirian, The Legal ity of Pre-Employment Credit Checks: A Proposed Model Statute to Remedy an Inequity, 20 VA. J. Soc. PoL'Y \& L. 159, 167-68 (2012) (The Society for Human Resources Management found that 13\% of businesses perform credit checks on all candidates and $47 \%$ on some candidates.); Taylore Karpa, Note, "An Equal Opportunity Employer": Proposed Judicial and Legislative Solutions to Restrict the Disparate Impact Caused by Employer use of Credit Checks, 49 New. ENG. L. Rev. 83, 85-86 (2014) (60\% of employ. ers use credit checks as a hiring tool, which is a $35 \%$ increase from 2001); Adam T. Klein, ReNika Moore \& Scott A. Moss, Employer Credit-History Checks and Criminal Record Checks of Job Applicants for Hiring Decisions: The Illegality Under Title VII Disparate Impact Doctrine, at The 13th Annual Corporate Counsel Institute, Georgetown University Law Center Continuing Legal Education, March 12-13, 2009, 2009 WL 2432291, at *1-6 (Mar. 12, 2009) (A 2004 study by the Society of Human Resource Management found that "[m]ore employers [we]re using credit checks in 2003 (35\%) compared to $1996(19 \%)^{n}$ as a way to "investigate the backgrounds of potential employees."); Lea Shepard, Seeking Solutions to Financial History Discrimination, 46 CONN. L. REv. 993, 1003-1005 (2014) (citing surveys showing that 60\% of employers used credit reports in 2010, compared to $35 \%$ of employers in 2003 and $19 \%$ in 1996).

${ }^{9}$ Concepción, supra note 8, at 537.39; Earle, Madek \& Missirian, supra note 8, at 167.68 (54\% of
} 
commentators on the question of whether an applicant's credit history is a fair predictor of whether the applicant might steal from his or her employer, or whether the applicant is mature, responsible, trustworthy, honest, reliable, has integrity, has good judgment, and is capable of handling the pressures of a job. ${ }^{10}$ The majority view among the commentariat is that credit history checks are unreliable proxies for the kind of characteristics that employers seek in job applicants. ${ }^{11}$ There are, however, commentators who reach the opposite conclusion. ${ }^{12}$

A credit check will disclose a bankruptcy, and on average, black and Latino $^{13}$ Americans have lower credit scores than white Americans ${ }^{14}$ partly

employers conducted credit checks in order to reduce the likelihood of theft, embezzlement, and other criminal activity; $27 \%$ did in order to manage legal liability for negligent hiring; $12 \%$ did in order to assess the overall trustworthiness of the applicant; $7 \%$ did in order to comply with applicable state laws that mandate background checks); Klein, Moore \& Moss, supra note 8, at *5-6; Shepard, supra note 8, at 1002 11.

${ }^{10}$ Concepción, supra note 8 , at 537.41 (there is little to no relationship between credit history and job performance); Earle, Madek \& Missirian, supra note 8, at 163-72 (there is a lack of demonstrable evidence connecting credit reports to predicting an applicant's criminal behavior or job performance); Klein, Moore \& Moss, supra note 8 , at *3.6 ("There is a complete absence of evidence that employee credit checks are job-related at all, much less consistent with business necessity, for any job - and there is substantial evidence that the credit records that employers check are based on factors substantially unrelated to any aspect of the performance of any job. To our knowledge, credit checks as a basis for employment decisions is a practice validated by no studies, much less by studies meeting the strict standard of proof justifying a job requirement imposing a disparate impact.") (emphasis in original); Lea Shepard, Toward a Stronger Financial History Antidiscrimination Norm, 53 B.C. L. REv. 1695, 1711-22 (2012) (noting that there is little empirical support for the proposition that employees or applicants for employment who have financial problems are more prone to commit theft, fraud, or accept bribes). But see Robert J. Landry \& Benjamin Hardy, Bankrupts Need Not Apply: Sound Hiring Policy or Dangerous Proposition?, 7 VA. L. \& Bus. REV. 47, 57.60 (2012) ("A past bankruptcy may serve as a proxy for responsibility, honesty, judgment, and good management skills, particularly when it comes to handling money or property." The authors also said that "drawing these kinds of conclusions about individuals based solely on bankruptcy status is stereotyping that may or may not be true in a given situation."); James D. Phillips \& David D. Schein, Utilizing Credit Reports for Employment Purposes: A Legal Bait and Suitch Tactic?, 18 RICH. J. L. \& PUB. INT. 133, 155 (2015) ("A 2004 study indicates that financial stress can impact work performance. While not an overwhelming number of studies validate the work performance - good credit link, there are at least some good quality and fairly recently reported studies [that] validate the use of credit reports for screening applicants.").

${ }^{11}$ Concepción, supra note 8, at 537-41; Earle, Madek \& Missirian, supra note 8, at 163-72; Klein, Moore \& Moss, supra note 8, at *3-6; Shepard, supra note 10, at 1711.22.

${ }^{12}$ Landry \& Hardy, supra note 10, at 57.60; Phillips \& Schein, supra note 10, at 153-55.

${ }^{13}$ I dislike the terms "Hispanic" and "Latino" because they both fail to account for the marked geographic, cultural, and in some instances, language differences that exist among the groups that the terms attempt to describe. On the other hand, a proper accounting of those differences in the course of a written or oral discussion can be unwieldy. For the purposes of this article, "Latino" includes persons of Mexican, Puerto Rican, Cuban, Central American, South American, or other Spanish origin countries or cultures, regardless of their race. 29 C.F.R. $\$ 1607.4(B)$.

${ }^{14}$ Concepción, supra note 8 , at $530-35$ (finding that counties with very low risk credit scores, those between 720 and 850 , had a population of $5 \%$ black and Latino while counties with very high risk credit scores, between 500 to 559 , had a population of $49 \%$ black and Latino. Moreover, this study found that $27 \%$ of whites have a bad credit record while $48 \%$ of blacks and $34 \%$ of Latinos have a bad credit record.); 
because black families are more than three times as likely to file bankruptcy as white families, and Latino families are almost twice as likely to file bankruptcy as white families. ${ }^{15}$ Black and Latino persons are overrepresented among bankruptcy filers, which means black and Latino persons are probably disproportionately impacted by employers' use of credit checks as a pre-employment screening device. ${ }^{16}$

Some believe that the primary reason people file bankruptcy is because of profligate spending. ${ }^{17}$ It is true that financial recklessness leads some to the doorsteps of the bankruptcy courthouse, but it is untrue that the majority of persons who file bankruptcy do so because they refused to cut up the credit card. ${ }^{18}$ Job losses, medical problems, and divorce account for $85 \%$ to $90 \%$ of bankruptcy filings, ${ }^{19}$ and in 2012 , the "median average monthly income" of the 1.1 million persons who filed for personal bankruptcy was $\$ 2,743$, while their "median average monthly expenses" were $\$ 2,769$, a mere $\$ 26$ difference. 20

Earle, Madek \& Missirian, supra note 8, at 186-87; Karpa, supra note 8, at 84, 88-89 (on average, whites have a $21 \%$ higher credit score than blacks); Klein, Moore \& Moss, supra note 8 , at *2 (blacks have bad credit records at a $21 \%$ higher rate than whites); Shepard, supra note 10, at 1042.

${ }^{15}$ Abbye Atkinson, Modifying Mortgage Discrimination in Consumer Bankruptcy, 57 ARIz. L. REV. 1041, 1074-75 (2015); Elizabeth Warren, The Economics of Race: When Making It to the Middle Is Not Enough, 61 WASH. \& LEE L. REV. 1777, 1786 (2004). The rates of bankruptcy filings by race come from a 2001 cross-sectional study of bankruptcy filers called the "2001 Consumer Bankruptcy Project." Atkinson, supra at 1074-75; Warren, supra at 1779, 1786.

${ }^{16}$ Concepción, supra note 8, at 526,529.41; Earle, Madek \& Missirian, supra note 8, at 161-72; Karpa, supra note 8, at 86-90; Klein, Moore \& Moss, supra note 8, at *1-6; Landry \& Hardy, supra note 10, at 54 . 56; Shepard, supra note 10, at 1010-13, 1041-44. But see Phillips \& Schein, supra note 10, at 156 ("While often alleged by opponents of the use of credit reports, the anecdotal evidence suggests that minorities are not necessarily disadvantaged by the use of credit reports.").

${ }^{17}$ Earle, Madek \& Missirian, supra note 8, at 167; Elizabeth Warren, The Over-Consumption Myth and Other Tales of Economics, Law, and Morality, 82 WAsH. U. L.Q. 1485, 1492-1503 (2004).

${ }^{18}$ Earle, Madek \& Missirian, supra note 8, at 167 ( ${ }^{4}$ People spend $21 \%$ less on clothing than they did in the early 1970's, and families today often conserve financial resources by shopping at low-cost, highvolume retailers such as $\mathrm{Wal}-\mathrm{Mart}$. The cost of appliances has dropped, but necessary expenses like mortgages, health insurance, transportation, and child care have increased dramatically. Families typically spend around $75 \%$ of their income on essential goods, leaving little room in the budget for luxury purchases."); Warren, supra note 17 , at 1492-1503.

${ }^{19}$ Concepción, supra note 8 , at 541 ; Warren, supra note 17 , at $1492-1503$.

${ }^{20}$ Office of Inspector General, United States Postal Service, Providing Non-Bank Financial Services for the Underserved, at 14, (Jan. 27, 2014), https://www.uspsoig.gov/sites/default/files/document-library. files/2015/rarc-wp-14-007_0.pdf (last visited May 14, 2016); 2012 Report of Statistics Required by the Bankruptcy Abuse Prevention and Consumer Protection Act of 2005 (Dec. 31, 2012), at 5, 6, http:// www.uscourts.gov/statistics/table/all/bankruptcy-abuse-prevention-and-consumer-protection-act-bapcpa /2012/12/31 (last visited July 25, 2017). “Debtors calculate their average monthly incomes and average monthly expenses and report them to the courts on line 16 of Schedule I (income) and line 18 of Schedule J (expenses). The [Administrative Office of the United States Courts] then calculates the median of the average monthly incomes reported by debtors for all districts and circuits." 2012 Report of Statistics Required by the Bankruptcy Abuse Prevention and Consumer Protection Act of 2005, supra at 6 n.2. (emphases added). 
Gainful employment is essential to obtaining financial stability or recovering from a financial setback. Denying a person a job because he or she is or was in bankruptcy is untenable if personal creditworthiness is not a reasonable measurement of job performance. ${ }^{21}$ A survey of the available case law shows that employers have refused to hire persons for the following positions because the applicants had once been debtors in bankruptcy: an unspecified job at a title company; ${ }^{22}$ a job as a project manager $;{ }^{23}$ an unspecified job with an insurance company; ${ }^{24} \mathrm{a}$ job as an executive assistant; ${ }^{25} \mathrm{a}$ job as a paralegal for a government contractor; ${ }^{26}$ and a job as a customer service representative at a bank. ${ }^{27}$ In each of these cases, the employer did not "look beneath" the applicant's bankruptcy filing to determine if the person actually lacked any of the personal character traits the employer wanted in an employee. ${ }^{28}$ Instead, the employers used bankruptcy status simpliciter as the reason to deny the person a job. 29

Personal creditworthiness can probably be linked to the successful performance of jobs that require financial expertise like hedge fund managers, investment portfolio managers, chief financial officers, stock or securities traders, or investment advisors. Thus, one should hesitate before quarreling with the notion that bankruptcy status should play some role in deciding whether to hire a person for those or similar jobs. The same cannot be said for an unspecified job at a title company, a job as a project manager, an unspecified job with an insurance company, a job as an executive assistant, a job as a paralegal for a government contractor, and a job as a customer service repre. sentative at a bank. ${ }^{30}$

\footnotetext{
${ }^{21}$ Griggs v. Duke Power Co., 401 U.S. 424, 436 (1971).

${ }^{22}$ Burnett v. Stewart Title, Inc. (In re Burnett), Bankruptcy No. 06-34312-H4-13, Adversary No. 08-03239, 2008 WL 4609983, at *1 (S.D. Tex. Oct. 14, 2008)

${ }^{23}$ Rea v. Federated Investors, 431 B.R. 18, 20 (W.D. Pa.), affd, 627 F.3d 937, 938-941 (3d Cir. 2010).

${ }^{24}$ Martin v. Am. Family Mut. Ins. Co. (In re Martin), Adversary No. 07-7067, Bankruptcy No. 06-41010, 2007 WL 2893431, at *1 (Bankr. D. Kan. Sept. 28, 2007).

${ }^{25}$ Leary v. Warnaco, Inc., 251 B.R. 656, 657 (S.D.N.Y. 2000).

${ }^{26}$ Fiorani v. CACI, 192 B.R. 401, 403.04 (E.D. Va. 1996).

${ }^{27}$ Pastore v. Medford Sav. Bank, 186 B.R. 553, 554 (D. Mass. 1995).

${ }^{28}$ In re Burnett, 635 F.3d 169 at 171; Rea, 627 F.3d at 938-39; In re Martin, 2007 WL 2893431, at *1; Leary, 251 B.R. at 657.59; Fiorani, 192 B.R. at 403.04; Pastore, 186 B.R. at 554.

${ }^{29}$ In re Burnett, 635 F.3d at 171; Rea, 627 F.3d at 938-39; In re Martin, 2007 WL 2893431, at *1; Leary, 251 B.R. at 656-57; Fiorani, 192 B.R. at 403-04, 407-09; Pastore, 186 B.R. at 554.

${ }^{30}$ There are those who maintain that working as a bank teller requires personal creditworthiness because tellers have access to and handle customers' money. Landry \& Hardy, supra note 10, at 48-49, 59; Phillips \& Schein, supra note 10, at 156. Tellers handle customers' money, but not in the sense that they make decisions about what a bank does with customers' money. Without trying to demean what tellers do, the essence of their job involves fairly simple transactions, namely, accepting customers' deposits, handling their withdrawals, cashing their checks, and the like. Further, tellers do this all under the watchful eye of security cameras, security personnel, and perbaps most importantly, the customers themselves. Thus, it is highly unlikely that a bank teller who has filed bankruptcy poses any more of a threat to steal a customer's money than a bank teller who has an impeccable credit history. Concepción, supra note 8 , at 539,545.46
} 
Bankruptcy debtors are not very sympathetic figures because of the persistent stereotype that they are financial deadbeats who are undeserving of a break. ${ }^{31}$ There are certainly financial deadbeats among the cohort of bankruptcy filers, but the idea that the dockets of the bankruptcy courts are swelled with them is a myth. ${ }^{32}$ One of the purposes of this Article is to counter the argument that bankruptcy debtors are fiscal scofflaws who should find it more difficult to obtain employment because their bankruptcy status makes them less worthy candidates for employment. The typical bankruptcy filer is not helped by being scorned or ridiculed by those fortunate enough to have steered clear of financial difficulty. A second purpose of this Article is to demonstrate that employers should stop refusing to hire a person because he or she is or was a debtor if personal creditworthiness is not related to successful performance of the job the person seeks, and the person is otherwise qualified for the job.

This Article is divided into four parts. Part I details the history of $\S 525(\mathrm{a})$ and $\S 525(\mathrm{~b})$. Part II discusses how the courts have addressed the question of whether $\$ 525$ (b) prohibits private employers from denying employment to persons who are or have been debtors. Part III addresses how bankruptcy discrimination implicates the disparate impact doctrine under $\mathrm{Ti}$ tle VII of the Civil Rights Act of 1964. Part IV shows just how many Americans live in financial peril and attempts to explode the myth that the reason they do is primarily because of their own irresponsibility.

\section{PEREZ V. CAMPBELL SET THE STAGE FOR THE ENACTMENT OF 11 U.S.C. $\$ 525$.}

On July 8, 1965, Adolfo Perez ("Mr. Perez") caused an automobile accident in Tucson, Arizona. ${ }^{33}$ The minor daughter of Leonard Pinkerton ("Mr. Pinkerton") drove the second vehicle. ${ }^{34}$ At the time of the accident, Mr. Perez did not have liability insurance on his vehicle. ${ }^{35}$ In September 1966, Mr. Pinkerton and his wife sued Mr. Perez and his wife in an Arizona state court for personal injuries and property damage. ${ }^{36}$ On October $31,1967, \mathrm{Mr}$. Perez and his wife confessed judgment, and on November 8, 1967, the state trial court entered a judgment against the Perezes in the amount of $\$ 2,425.98 .{ }^{37}$

(arguing that there is no evidence correlating an employee's negative credit history with a propensity to steal).

${ }^{31}$ Concepción, supra note 8, at 541; Warren, supra note 17, at 1492-1503.

${ }^{32}$ Concepción, supra note 8, at 541; Warren, supra note 17, at 1492-1503.

${ }^{33}$ Perez v. Campbell, 402 U.S. 637, 638 (1971).

${ }^{34} I d$.

${ }^{35} I d$.

${ }^{36} \mathrm{Id}$. Mr. Perez and Mrs. Perez jointly owned the vehicle Mr. Perez drove. Perez v. Campbell, 421 F.2d 619, 621 (9th Cir. 1970), rev'd, 402 U.S. 637, 656 (1971).

${ }^{37}$ Perez, 402 U.S. at 638. 
On November 6, 1967, two days before the state trial court entered a judgment against them, the Perezes filed bankruptcy, and they included in their list of debts the judgment they confessed to on October 31, 1967.38 On July 8,1968 , the Perezes received a discharge that included the $\$ 2,425.98$ judgment in favor of the Pinkertons. ${ }^{39}$ At the time, Arizona and forty-four other states had in effect some version of the Uniform Motor Vehicle Safety Responsibility Act, which was promulgated by the National Conference on Street and Highway Safety..$^{40}$ Arizona called its version the Arizona Motor Vehicle Safety Responsibility Act ("Arizona Act"). ${ }^{41}$

Under Article 4 of the Arizona Act, if a judgment for damages "arising out of the ownership, maintenance[,] or use of a motor vehicle" remained unsatisfied for sixty days after its entry, the state court clerk or the state court judge had to forward a certified copy of the judgment to the Superintendent of the Motor Vehicle Division of the Highway Department ("Superintendent") ${ }^{42}$ Once the Superintendent received a certified copy of a judgment, he or she had to suspend the driver's license and vehicle registration of the judgment debtor, and the suspension remained in effect until the judgment debtor satisfied the judgment and gave proof of financial responsibility for a future period. ${ }^{33}$ The Arizona Act also provided that "a discharge in bankruptcy following the rendering of any such judgment shall not relieve the judgment debtor from any of the requirements of [Article 4]. ${ }^{n 4}$

On March 13, 1968, 126 days after the state trial court entered the judg. ment against the Perezes and 117 days before they received a discharge, the Superintendent notified the Perezes that their drivers' licenses and vehicle registrations were suspended. ${ }^{45}$ The Perezes then filed a complaint in federal district court claiming, among other things, that the part of the Arizona Act that conditioned the renewal or issuance of a driver's license and vehicle registration on the satisfaction of a debt that had been discharged in bankruptcy conflicted with the Bankruptcy Act and violated the Supremacy

${ }^{38}$ Id. at 638.39 .

${ }^{39} \mathrm{Id}$. at 639 .

${ }^{40} \mathrm{Id}$. at 665 n.6 (Blackmun, J., dissenting). Besides Arizona, the other states that had enacted some version of the Uniform Motor Vehicle Safety Responsibility Act were: Alabama, Alaska, Arkansas, California, Colorado, Connecticut, Delaware, Hawaii, Idaho, Illinois, Iowa, Kansas, Kentucky, Louisiana, Maine, Maryland, Michigan, Minnesota, Mississippi, Missouri, Montana, Nebraska, Nevada, New Hampshire, New Jersey, New Mexico, New York, North Carolina, North Dakota, Ohio, Oklahoma, Pennsylvania, Rhode Island and Providence Plantations, South Carolina, South Dakota, Tennessee, Texas, Utah, Vermont, Virginia, Washington, West Virginia, Wisconsin, and Wyoming. Perez invalidated all of these states laws. Id. at 654-56.

${ }^{41} I d$. at 639.

${ }^{42} I d$. at 641 .

${ }^{43} \mathrm{Id}$. at $641 \cdot 42$.

${ }^{44} I d$.

${ }^{45}$ Id. 
Clause of the Constitution. ${ }^{46}$ The district court dismissed the Perezes' complaint, finding that Kesler v. Department of Public Safety Financial Responsibility Division, State of Utah, ${ }^{47}$ and Reitz v. Mealey, ${ }^{48}$ had both rejected the argument that state laws conditioning the issuance or renewal of a driver's license on satisfying judgments stemming from automobile accidents, even. when those judgments had been discharged in bankruptcy, conflicted with the Bankruptcy Act. ${ }^{49}$ The United States Court of Appeals for the Ninth Circuit affirmed the district court on the same grounds. ${ }^{50}$ The Perezes then filed a petition for a writ of certiorari with the Supreme Court of the United States, asking it to consider the constitutionality of

the power of a State to include as part of [a] comprehensive enactment designed to secure compensation for automobile accident victims in a section providing that a discharge in bankruptcy of the automobile accident or tort judgment shall have no effect on the judgment debtor's obligation to repay the judgment creditor, at least insofar as such repayment may be enforced by the withholding of driving privileges by the State. ${ }^{51}$

The Court began its analysis by finding that the Supreme Court of Arizona had construed the Arizona Act to be primarily concerned with protecting persons who use the highways from the financial hardship that might result from financially irresponsible persons operating motor vehicles on those highways. ${ }^{52}$ Next, the Court repeated what it had stated several times before, namely that "one of the primary purposes of the Bankruptcy Act is to give debtors a new opportunity in life and a clear field for future effort, unhampered by the pressure and discouragement of preexisting debt., ${ }^{53}$ This "new opportunity" included the freedom from most preexisting tort judg. ments. ${ }^{54}$ The Court then asked "whether a state statute that protects judg. ment creditors from financially irresponsible persons conflicts with a federal statute that gives discharged debtors a new start unhampered by the pressure and discouragement of preexisting debt[?]"55

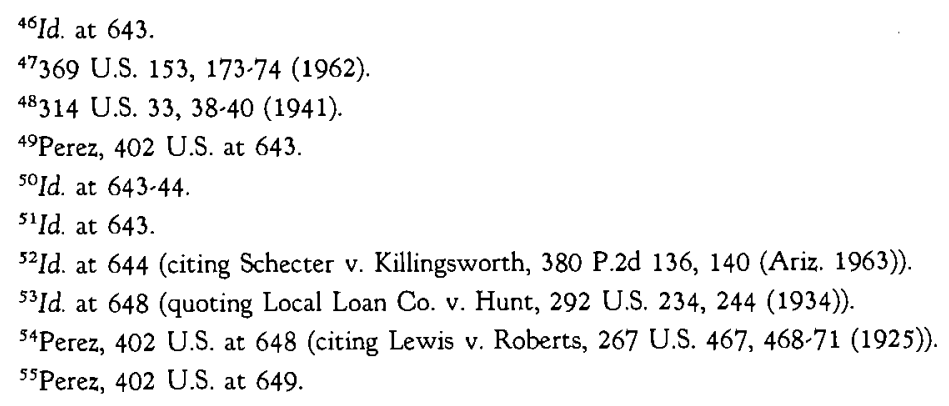


Relying on Chief Justice John Marshall's opinion in Gibbons v. Ogden, ${ }^{56}$ which held that acts of the states that interfere with or are contrary to the laws of Congress are invalid under the Supremacy Clause, and Justice Hugo Black's majority opinion in Hines $v$. Davidowitz, ${ }^{57}$ which concluded that the Court's function in Supremacy Clause cases is to determine whether a state statute "stands as an obstacle to the accomplishment and execution of the full purposes and objectives of Congress," the Court held that Kesler and Reitz "ignored [those] controlling principle[s]." 58 The Court then overruled Kesler and Reitz, and held that the part of the Arizona Act that conditioned the issuance or renewal of a driver's license and a vehicle registration on the satisfaction of a judgment stemming from a motor vehicle accident, even if that judgment had been discharged in bankruptcy, violated the Supremacy Clause because it frustrated the "full effectiveness" of the Bankruptcy Act, which was intended to give debtors "a new start unhampered by the pressure and discouragement of preexisting debt." 59

\section{A. Congress codified Perez in the Bankruptcy Reform Act OF 1978.}

On April 4, 1800, the Sixth Congress enacted the nation's first federal bankruptcy law. ${ }^{60}$ The debate surrounding the law was polarized, with commercial interests supporting it and southern and agricultural interests opposing it.61 Ultimately, the law passed by one vote in the House of Representatives. ${ }^{62}$ The 1800 law was a compromise measure, and Congress intended for it to expire in 1805, however, the Eighth Congress repealed it on December 19, 1803.63

On August 19, 1841, the Twenty-Seventh Congress passed the Bankruptcy Act of $1841 .{ }^{64}$ The 1841 law differed substantially from the 1800 law in that it allowed a debtor to file bankruptcy and seek a discharge of his debts, which was a first in the history of federal bankruptcy law. ${ }^{65}$ The 1841

${ }^{56} 22$ U.S. 1, 211 (1824).

${ }^{57} 312$ U.S. $52,67(1941)$

${ }^{58}$ Perez, 402 U.S. at 649-50.

${ }^{59} I d$. at $651-52$. The Court described Kesler and Reitz as "aberrational" because they held that state law could frustrate the operation of federal law so long as the state legislature that enacted the law did not do so for the purpose of frustrating the operation of federal law. Id.

${ }^{60}$ Charles Jordan Tabb, The History of the Bankruptcy Laws in the United States, 3 AM. BANkr. INsT. L. Rev. 5, 6-7, 14-15 (1995). Professor Tabb's article is a thorough history and commentary on bankruptcy law in England from 1542 to 1732 and in the United States from 1800 to 1994. Id. at 7-12, 12-43.

${ }^{61} \mathrm{Tabb}$, supra note 60 , at 14 .

${ }^{62} \mathrm{Id}$.

${ }^{63} I d$.

${ }^{64} I d$. at 16. Following the 1803 repeal, state legislation filled the gap left by the absence of federal bankruptcy law. Id. at 15 .

${ }^{65} I d$. at 17 . 
law displeased creditors because they received paltry dividends and paid high administrative costs. ${ }^{66}$ Consequently, the same Congress that enacted the 1841 law repealed it eighteen months later on March 3, 1843.67

On March 2, 1867, the Thirty-Ninth Congress passed the Bankruptcy Act of $1867 . .^{68}$ This iteration of bankruptcy law differed from its 1841 predecessor in that it included provisions for voluntary and involuntary bankruptcies as well as corporate bankruptcies. ${ }^{69}$ Creditors objected to the 1867 law on substantially the same grounds as they did to the 1841 law, namely, low dividend payouts, high costs, and the lengthy amount of time it took for bankruptcy cases to conclude. $7^{70}$ Again, Congress responded to the critics, and on June 7, 1878, the Forty.Fifth Congress repealed the 1867 law. ${ }^{71}$

On July 1, 1898, the Fifty-Fifth Congress enacted the Bankruptcy Act of 1898.72 Professor Charles Jordan Tabb describes the 1898 law as the "beginning of the era of permanent federal bankruptcy legislation. ${ }^{73}$ The next major revision to federal bankruptcy law occurred on June 22, 1938, when the Seventy-Fifth Congress passed the Chandler Act, which Professor Tabb argues "substantially revised [nearly the entire] 1898 law and thoroughly updated the substantive and procedural law of liquidation cases." 74

On November 6, 1978, the Ninety-Fifth Congress enacted the Bankruptcy Reform Act of $1978^{75}$ in order to modernize and codify the substantive law of bankruptcy and to enact much of the procedural law of bankruptcy in Title 11 of the United States Code. ${ }^{76}$ The 1978 law was Congress's first comprehensive reform of federal bankruptcy law since the Chandler Act four decades earlier, and it was the first comprehensive reform that did not result from Congress responding to a severe economic depression. 77 The 1978 law serves as the foundation of modern bankruptcy law. ${ }^{78}$ The 1978 law included 11 U.S.C. $\$ 525$, which provided in relevant part:

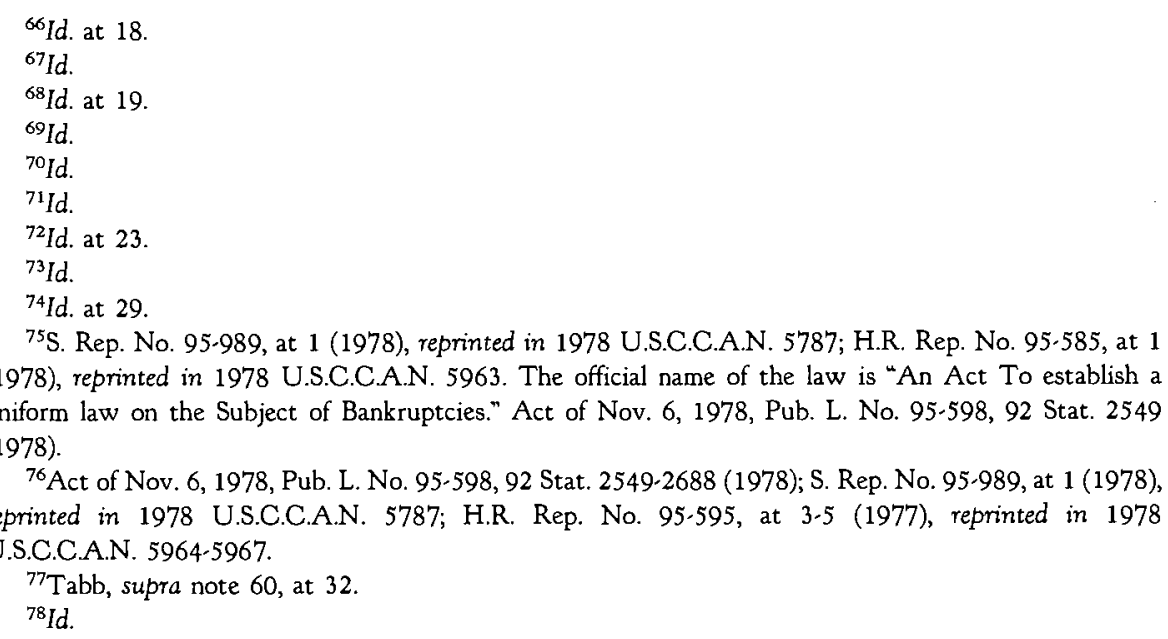


A governmental unit may not deny, revoke, suspend, or refuse to renew a license, permit, charter, franchise, or other similar grant to, condition such a grant to, discriminate with respect to such a grant against, deny employment to, terminate the employment of, or discriminate with respect to employment against, a person that is or has been a debtor under this title or a bankrupt or a debtor under the Bankruptcy Act, or another person with whom such bankrupt or debtor has been associated, solely because such bankrupt or debtor is or has been a debtor under this title or a bankrupt or debtor under the Bankruptcy Act, has been insolvent before the commencement of the case under this title, or during the case but before the debtor is granted or denied a discharge, or has not paid a debt that is dischargeable in the case under this title or that was discharged under the Bankruptcy Act.79

Congress enacted $\S 525$ in order to provide additional protection to debtors by codifying the holding in Perez "that a State would frustrate the Congressional policy of a fresh start for a debtor if it were permitted to refuse to renew a driver[']s license because a tort judgment resulting from an automobile accident had been unpaid as a result of a discharge in bankruptcy." 80 Section 525 prohibits governmental units from denying employment to, terminating the employment of, or discriminating with respect to employment against a person who is or has been a debtor, or who is or has been associated with a debtor. ${ }^{81}$ Section 525 's anti-discrimination principle applies only to acts of discrimination that are based solely on the basis of bankruptcy, or on the basis of insolvency before or during bankruptcy prior to a determination of discharge, or on the basis of the non-payment of a debt that has been discharged in bankruptcy. ${ }^{82}$ It does not ban discrimination based on nonbankruptcy considerations such as future financial responsibility or ability, so long as those considerations are applied in a non-discriminatory fashion. ${ }^{83}$

By specifying prohibited forms of discrimination in $\$ 525$, Congress did not intend to allow other forms. ${ }^{84}$ Congress contemplated that courts would

\footnotetext{
${ }^{79}$ Act of Nov. 6, 1978, Pub. L. No. 95-598, Title I, § 525, 92 Stat. 2549, 2593 (1978) (emphases added).

${ }^{80}$ S. Rep. No. 95-989, at 81 (1978), reprinted in 1978 U.S.C.C.A.N. 5867; H.R. Rep. No. 95-595, at 366 (1977), reprinted in 1978 U.S.C.C.A.N. 6322.

${ }^{81} 11$ U.S.C. $\S 525$.

${ }^{82} I d$.

${ }^{83}$ S. Rep. No. 95-989, at 81 (1978), reprinted in 1978 U.S.C.C.A.N. 5867; H.R. Rep. No. 95-595, at 366 (1977), reprinted in 1978 U.S.C.C.A.N. 6322-23.

${ }^{84}$ S. Rep. No. 95-989, at 81 (1978), reprinted in 1978 U.S.C.C.A.N. 5867 (" $[$ T $]$ he section is not exhaustive. The enumeration of various forms of discrimination against former bankrupts is not intended to
} 
continue to develop and refine Perez by prohibiting acts by "governmental or quasi-governmental units that perform licensing functions, such as a State bar association or a medical society, or by other organizations that can seriously affect the debtor[']s livelihood or fresh start, such as exclusion from a union on the basis of discharge of a debt to the union's credit union." ${ }^{85}$ Section 525 as originally enacted did not prohibit bankruptcy discrimination by private parties, which is an omission that Congress intended. ${ }^{86}$

\section{B. Congress enacted 11 U.S.C. $§ 525$ (B) In The Bankruptcy AMENDMENTS AND FEDERAL Judgeship ACT OF 1984.}

In addition to codifying the substantive and procedural law of bankruptcy in Title 11 of the United States Code, the Bankruptcy Reform Act of 1978 granted bankruptcy judges jurisdiction over "all civil proceedings arising under [T] itle 11 or arising in or related to cases under [T]itle $11 . " 87$ This jurisdictional grant authorized bankruptcy courts to preside over suits to recover accounts, cases involving exempt property, actions to avoid transfers and payments as preferences or fraudulent conveyances, and causes of action owned by the debtor at the time of the petition for bankruptcy.88 The bankruptcy courts could also decide claims based on state law or federal law. .89 Unlike Article III judges, ${ }^{90}$ however, the judges of the bankruptcy courts do not have life tenure, ${ }^{91}$ and their salaries can be reduced if Congress chooses to

permit other forms of discrimination."); H.R. Rep. No. 95-595, at 366 (1977), reprinted in 1978 U.S.C.C.A.N. 6323 (same).

${ }^{85}$ S. Rep. No. 95.989, at 81 (1978), reprinted in 1978 U.S.C.C.A.N. 5867; H.R. Rep. No. 95.595, at 366 (1977), reprinted in 1978 U.S.C.C.A.N. 6323.

${ }^{86}$ S. Rep. No. 95-989, at 81 (1978), reprinted in 1978 U.S.C.C.A.N. 5867 ("This section is not so broad as a comparable section proposed by the Bankruptcy Commission, H.R. 31, 94th Cong., 1st Sess. $§ 4-508$ (1975), [that] would have extended the prohibition to any discrimination, even by private parties.); H.R. Rep. No. 95-595, at 366 (1977), reprinted in 1978 U.S.C.C.A.N. 6323 (same).

${ }^{87}$ Act of Nov. 6, 1978, Pub. L. No. 95-598, Title II, § 241(a), 92 Stat. 2549, 2657, 2668-69 (1978) (codified as 28 U.S.C. $\$ 1471$ (b) (1976 \& Supp. IV)).

${ }^{88}$ N. Pipeline Constr. Co. v. Marathon Pipe Line Co., 458 U.S. 50,54 (1982) (plurality opinion).

${ }^{89}$ Id. at 54 (citing 1 Collier ON BANKRUPTCY I 3.01, 3-47 - 3.48 (15th ed. 1982)).

${ }^{9}$ Article III, $\S 1$ of the Constitution provides: "The Judges, both of the supreme and inferior Courts, shall hold their Offices during good Behaviour, and shall, at stated Times, receive for their Services, a Compensation, which shall not be diminished during their Continuance in Office." U.S. Const. art. III, $\S 1$. The "good Behaviour" Clause has been construed to mean that Article III judges have life tenure, subject only to removal by impeachment. Marathon, 458 U.S. at 59 (citing United States $e x$ rel. Toth v. Quarles, 350 U.S. 11, 16(1955)). The "Compensation" Clause has been construed to mean that Article III judges' salaries cannot be reduced. Id. (citing United States v. Will, 449 U.S. 200, 218-21 (1980)).

${ }^{91}$ Bankruptcy judges were appointed by the President, subject to the advice and consent of the Senate. Act of Nov. 6, 1978, Pub. L. No. 95-598, Title II, § 201(a), 92 Stat. 2549, 2657 (1978) (codified as 28 U.S.C. $\$ 152$ (1976 \& Supp. IV)). The judges served fourteen year terms and could be removed from office for incompetency, misconduct, neglect of duty, or physical or mental disability. Act of Nov. 6, 1978, Pub. L. No. 95-598, Title II, $\S 201$ (a), 92 Stat. 2549, 2657-2658 (1978) (codified as 28 U.S.C. $\S \S 153(a)$, (b) (1976 \& Supp. IV)). 
do so. ${ }^{92}$

On June 28, 1982, the Supreme Court decided Northern Pipeline Construction Co. v. Marathon Pipe Line Co. ${ }^{93}$ The question presented in the case was whether the broad jurisdictional grant that Congress conferred on bankruptcy courts in the Bankruptcy Reform Act of 1978 violated Article III of the Constitution. ${ }^{94}$ In a plurality opinion joined by Justices Thurgood Marshall, Harry Blackmun, and John Paul Stevens, Justice William Brennan wrote that "Art[icle] III bars Congress from establishing legislative courts to exercise jurisdiction over all matters related to those arising under the bankruptcy laws." 95 The plurality concluded that the broad jurisdictional grant that Congress conferred on bankruptcy courts in the Bankruptcy Reform Act of 1978 "impermissibly removed most, if not all, of "the essential attributes of the judicial power' from the Art[icle] III district court, and [ ] vested those attributes in a non-Art[icle] III adjunct." 96

On July 10, 1984, the Ninety-Eighth Congress responded to the Marathon decision by enacting the Bankruptcy Amendments and Federal Judgeship Act of $1984 . .^{97}$ Although the Ninety-Fifth Congress specifically declined to ban private parties from engaging in bankruptcy discrimination, the Ninety-Eighth Congress took a different tack. ${ }^{98}$ In addition to curing the constitutional defects in the 1978 law as exposed by the Marathon decision, the 1984 amendments renumbered 11 U.S.C. $\S 525$ as $\$ 525(\mathrm{a})$, and added a new section, $\$ 525(\mathrm{~b})$, which provided as follows:

No private employer may terminate the employment of, or discriminate with respect to employment against, an individual who is or has been a debtor under this title, a debtor or bankrupt under the Bankruptcy Act, or an individual associated with such debtor or bankrupt, solely because such debtor or bankrupt: (1) is or has been a debtor under this title or a debtor or bankrupt under the Bankruptcy Act; (2) has been insolvent before the commencement of a case under this title or during the case but before the grant or denial of a discharge; or (3) has not paid a debt that is dischargeable in

\footnotetext{
${ }^{92}$ Act of Nov. 6, 1978, Pub. L. No. 95-598, Title II, $\$ 201$ (a), 92 Stat. 2549, 2657-58 (1978) (codified as 28 U.S.C. $\S 154$ (1976 \& Supp. IV)).

${ }^{93} 458$ U.S. 50 (1982).

${ }^{94}$ Marathon, 458 U.S. at 52.53 .

${ }^{95} \mathrm{Id}$. at 76 .

${ }^{96} \mathrm{Id}$. at 87.

${ }^{97}$ Pub. L. No. 98-353, 98 Stat. 333-392 (1984); H.R. Rep. No. 98-882 (1984) (Conf. Rep.), reprinted in 1984 U.S.C.C.A.N. 576-606.

${ }^{98}$ Bankruptcy Amendments and Federal Judgeship Act of 1984, Pub. L. No. 98-353, Title III, $\S 309$, 98 Stat. 333, 352, 354.55 (1984).
} 
a case under this title or that was discharged under the Bankruptcy Act. 99

Congress enacted $\S 525(\mathrm{~b})$ in order to extend the anti-discrimination principle that $\$ 525(\mathrm{a})$ applied to government employers to private employ. ers. ${ }^{100}$ Prior to 1984 , private employers were free to terminate a person's employment based solely on his or her filing bankruptcy. ${ }^{101}$ The language of $\S 525$ (b) mirrors the language of $\S 525(\mathrm{a})$ with one significant exception. Section 525(a) prohibits a government employer from "deny[ing] employment to, terminat [ing] the employment of, or discriminat [ing] with respect to employ. ment against [a debtor], whereas $\S 525$ (b) prohibits a private employer from "terminat[ing] the employment of, or discriminat[ing] with respect to employment against [a debtor]. ${ }^{102}$ The absence of the "deny employment to" language in $\S 525(\mathrm{~b})$ raises the question of whether a private employer can or should refuse to hire a person because he or she is or was a debtor. ${ }^{103}$

${ }^{99}$ Bankruptcy Amendments and Federal Judgeship Act of 1984, Pub. L. No. 98-353, Title III, $\$ 309$, 98 Stat. 333, 352, 354.55 (1984) (emphasis added). Section 525(b) became effective for cases filed on or after October 9, 1984. Bankruptcy Amendments and Federal Judgeship Act of 1984, Pub. L. No. 98-353, Title III, § 553(a), 98 Stat. 333, 352, 392 (1984).

${ }^{100}$ The legislative history of the Bankruptcy Amendments and Federal Judgeship Act of 1984, which includes $\S 525(\mathrm{~b})$, consists solely of statements by the following legislators: Representative Peter W. Rodino, Jr., Representative Robert W. Kastenmeier, Senator Strom Thurmond, Senator Robert J. Dole, and Senator Orrin G. Hatch. 1984 U.S.C.C.A.N. 576-78 (Representative Rodino); $579-580$ (Representative Kastenmeier); 581.85 (Senator Thurmond); 586.89 (Senator Dole); 590.606 (Senator Hatch). Neither the Senate nor the House submitted a report, and the House Conference Report did not contain a joint explanatory statement. 1984 U.S.C.C.A.N. 576. By way of comparison, the legislative history of the Bankruptcy Reform Act of 1978 consists of a 176 page Senate Report, a 549 page House Report, a 70 page statement by Representative Don Edwards, and a 70 page statement by Senator Dennis DeConcini. 1984 U.S.C.C.A.N. 6436-6505 (Representative Edwards); 6505-6573 (Senator DeConcini).

${ }^{101}$ In re Stinson, 285 B.R. at 241 n.5 (citing McLellan v. Miss. Power \& Light Co., 545 F.2d 919, 929 . 30 (5th Cir. 1977) (en banc)).

${ }^{102}$ Compare 11 U.S.C. § 525(a), with 11 U.S.C. \$ 525(b).

${ }^{103}$ Douglass G. Boshkoff, Bankruptcy-Based Discrimination, 66 AM. BANkr. LJ. 387, 391.97 (1992) (courts that read $\$ 525$ (b) to allow an employer to refuse to hire a debtor "interfere with the rebabilitative features of bankruptcy law"); Douglass G. Boshkoff, Private Parties and Bankruptcy-Based Discrimination, 62 IND. L.J. 159174.82 (1987) (even though the text of $\$ 525(\mathrm{~b})$ gives private employers more freedom to discriminate based on bankruptcy status, private employers should be prohibited from engaging in bankruptcy discrimination just as governmental employers are prohibited); John C. Chobot, Anti-Discrimination Under the Bankruptcy Laws, 60 AM. BANKR. L.J. 185, 196-201 (1986) (one can argue persuasively that Congress intended to narrow the scope of bankruptcy discrimination protection when it omitted the "deny employment to" language from $\$ 525(\mathrm{~b})$ ); Donald C. Dowling, Jr., The Intersection Between U.S. Bankruptcy and Employment Law, 10 LAB. LAW. 57, 70-72 (1994) ("Overall, [United States] law generally protects workers at the expense of employers, both in employer bankruptcies and in workers' bankruptcies."); Karyn D. Heavenrich, Student Gallery, Are Fair Employment Practices after Bankruptcy a Human Right?, 32 AM. BANKR. INST. J., Feb. 2013, at 36-37 (reading $§ 525$ (b) to allow private employers to refuse to hire a debtor is sound statutory interpretation, but refusing to hire a debtor with no regard for why the person is or was a debtor and without considering the debtor's non-bankruptcy related qualifications violates the debtor's human rights); Andrew N. Herbach, Debtor's Protection from Private Employer's Dis. crimination, 61 WIs. B. BuLl., Oct. 1988, at 21.23 (\$ 525(b) does not protect an employee from termina- 
tion for non-bankruptcy reasons such as poor job performance, and a person claiming a violation of $\S 525$ (b) has the burden of proving that the employer acted solely because of the person's bankruptcy status) (emphasis in original); Michael R. Herz, The Scarlet D: Bankruptcy Filing and Employment Discrimination, 30 AM. BANKR. INST. J., Apr. 2011, at 16 (courts cannot be faulted for interpreting $\$ 525(\mathrm{~b})$ to allow private employers to refuse to hire debtors, however, that interpretation frustrates the fresh start goal of the Bankruptcy Code, thus, Congress should amend $\$ 525(\mathrm{~b})$ to prohibit private sector bankruptcy discrimination); Robert J. Landry \& Benjamin Hardy, Bankrupts Need Not Apply: Sound Hiring Policy or Dangerous Proposition?, 7 VA. L. \& Bus. Rev. 47, 51, 57.60 (2012) (employers should be allowed to base hiring decisions on bankruptcy status because a bankruptcy can be an indicator of an applicant's responsibility, honesty and other "soft skills [that are important to successful job performance ...., but ]are difficult to detect in the hiring process"); Jeanette E. McPherson, The Anti-Discrimination Provision Does Not Apply to Private Employers Who Deny Employment Based Upon Bankruptcy Status, 20 NORTON J. BANKR. L. \& Prac. 6 Art. 4 (Dec. 2011) (reading $\$ 525($ b) to allow private employers to refuse to hire debtors is a sound application of the "canons of statutory interpretation ... [,h]owever, with the tough economic times in which we live, and the attendant increase in bankruptcy filings, time will tell whether $\$ 525[(\mathrm{~b})]$ will continue to be analyzed so strictly without consideration to its overall purpose or if it will be amended by Congress to protect those who are denied employment due to their bankruptcy status."); Michael D. Moberly, Contemplating the Recognition of a Common Law Tort for Wrongfully Refusing to Hire Bank. ruptcy Debtors, 22 AM. BANKR. INST. L. REV. 431, 481-86 (2014) (There is nothing "irrational, unusual, or objectionable $e^{n}$ about Congress's decision to prohibit governmental employers from refusing to hire debtors while allowing private employers to do just that given the political dynamics of lawmaking. Any expansion of $\$ 525$ (b) should come from Congress, not the courts.); Sharon Goott Nissim, Stopping a Vicious Cycle: The Problems with Credit Checks in Employment and Strategies to Limit Their Use, 18 GEO. J. ON POV. ERTY L. \& POL'Y 45, 48-49, 70-78 (2010) (Given the disparate racial impact on the use of credit checks which will disclose bankruptcies - as employment screening devices, Congress and the states should enact legislation to prohibit the use of credit checks in the employment application process except "... for positions in which the employee would have access to significant cash or other financial or business assets, and positions that have access to confidential or secure information."); Samantha Orovitz, Comment, The Bankruptcy Shadow: Section 525(b) and the Job Applicant's Sisyphean Struggle for a Fresh Start, 29 EM. ORY BANKR. DEV. J. 553,589.590, 594-600 (2013) (Denying employment to a person because he or she is or was a debtor is "unreasonable and unnecessarily punitive," therefore, Congress should amend $\S 525(\mathrm{~b})$ to prohibit the practice.); James D. Phillips \& David D. Schein, Utilizing Credit Reports for Employment Purposes: A Legal Bait and Switch Tactic?, 18 Rich. J.L. \& PUB. INT. 133, 152-57 (2015) (Private employers are "rational actors" and would not use screening tools like credit reports if those tools did not result in hiring better applicants. Also, "employers expect [ ] applicants to pay their bills . . as this may [indicate the kind] of ethical behavior [they] will practice [if hired.]"; Katherine Porter \& Deborah Thorne, The Failure of Bankruptcy's Fresh Start, 92 CORNELL L. Rev. 67,100-09, 125-28 (2006) (The authors analyzed data from 2001 to 2003 that was part of "Phase III of the Consumer Bankruptcy Project," which collected data from debtor questionnaires, public court records, and telephone interviews. The authors concluded that Chapter 7 bankruptcy does not "ensure lasting financial well-being" for one-third of families that seek its protection because post-bankruptcy, these families experience a decline in their income often because of job or medical problems. They also stated that notwithstanding the probibition on terminating a person for filing bankruptcy, it happens nevertheless); Lea Shepard, Seeking Solutions to Financial History Dis. crimination, 46 CONN. L. Rev. 993, 1029-30 (2014) (noting that 25\% of employers consider bankruptcy filings in making employment decisions and $\$ 525(\mathrm{~b})$ authorizes private employers to refuse to hire a person on this basis. She argues that this practice "promotes discrimination."); Lea Shepard, Toward a Stronger Financial History Antidiscrimination Norm, 53 B.C. L. REV. 1695, 1756-61 (2012) (citing a 2008 study stating that $45 \%$ of persons who were denied employment after filing bankruptcy reported that the denial was "attributable to the bankruptcy filing." The author argued that "[b]ankruptcy antidiscrimination protection is [a necessary, but not sufficient] component of an effective and comprehensive financial history antidiscrimination norm."); Robert C. Yan, Note: The Sign Says "Help Wanted, Inquire Within" But it May Not Matter if You Have Ever Filed (or Plan to File) for Bankruptcy, 10 AM. Bankr. Inst. L. REV. 429, 457.59, 461.62 (2002) (The correct interpretation of $\S 525(\mathrm{~b})$ is that it does not reach private 


\section{DOES $\S 525(\mathrm{~B})$ PROHIBIT A PRIVATE EMPLOYER FROM REFUSING TO HIRE A DEBTOR?}

Three United States circuit courts, ${ }^{104}$ two United States district courts, ${ }^{105}$ and two United States bankruptcy courts ${ }^{106}$ have held that $\S 525$ (b) does not prohibit a private employer from refusing to hire a debtor. Six United States bankruptcy courts have held that $\S 525(\mathrm{~b})$ is only available to persons once an employer - employee relationship has formed, and if an employer refuses to hire a person, that person cannot use $\S 525(\mathrm{~b})$ because he or she was never an employee of the employer. ${ }^{107}$ One United States district court has held that $\S 525$ (b) prohibits private employers from refusing to hire debtors in the same way that $\S 525(\mathrm{a})$ prohibits government employers from refusing to hire debtors. ${ }^{108}$ Finally, one United States circuit court has sug. gested that if an employer's sole reason for refusing to hire a person is because the person is or was a debtor, that employer could be subject to a cause of action under $\S 525(\mathrm{~b}){ }^{109}$

\section{A. The Majority View is that $\S 525(\mathrm{~B})$ DOES NOT APPLy to HIRING DECISIONS.}

The courts that have held that $\S 525$ (b) does not apply to hiring decisions reached that conclusion using established canons of statutory interpretation. ${ }^{10}$ As previously noted, $\S 525(\mathrm{a})$ prohibits government employers

sector discrimination based on bankruptcy status. Such a reading frustrates the fresh start principle of the Bankruptcy Code, but if $\S 525(\mathrm{~b})$ is to be changed in a manner consonant with this principle, Congress is the proper body to make that change.); Jina Kim Yun, Note, The New Danger of Being Fired: Section 525(b)'s Disproportionate Effect on Older Workers and a Call to Amend, 7 Nw. J. L. \& Soc. PoL'Y 196, $196-99,216-18$ (2012) (The absence of the "deny employment to" language in $\$ 525(\mathrm{~b})$ has bad an "overly punitive" impact on debtors, particularly older ones. The remedy for this impact, however, should be legislative rather than judicial.); David L. Zeiler, Section 525(b): Anti-Discrimination Protection for Em. ployees/Debtors in the Private Sector - Is it Illusion or Reality?, 101 CoM. L.J. 152, 163-176 (1996) (When Congress enacted $\S 525$ in 1978 , it announced a broad antidiscrimination principle. Congress recognized courts' authority to more specifically define the "contours" of this principle and invited them to do so. When Congress enacted $\$ 525$ (b) in 1984, however, most courts declined that invitation and interpreted the section narrowly, which frustrated the fresh start principle of the Bankruptcy Code and thereby rendered $\$ 525$ (b)'s protection illusory.)

${ }^{104}$ Myers, 640 F.3d at 1283-87; In re Burnett, 635 F.3d at 171-74; Rea, 627 F.3d at 940-41.

${ }^{105}$ Fiorani, 192 B.R. at 404-07; Pastore, 186 B.R. at 554-55.

${ }^{100}$ In re Martin, 2007 WL 2893431, at "1-5; In re Stinson, 285 B.R. at 241-50.

${ }^{107}$ In re Hardy, 209 B.R. 371, 374-79 (Bankr. E.D. Va. 1997); In re Bobbitt, 174 B.R. 548, 552 (Bankr. N.D. Cal. 1993); In re Briggs, 143 B.R. 438, 443-45 (Bankr. E.D. Mich. 1992); In re Henry, 129 B.R. 75, 78 (Bankr. E.D. Va. 1991); In re Spaulding, 116 B.R. at 569, 571-73; In re Hopkins, 81 B.R. 491, 494 (Bankr. W.D. Ark. 1987); In re Madison Madison Int'l of Ill., P.C., 77 B.R. at 680-82).

${ }^{108}$ Leary, 25l B.R. at 658.59.

${ }^{109}$ Comeaux, 915 F.2d at 1268.69 .

${ }^{110}$ Myers, 640 F.3d at 1280-87; In re Burnett, 635 F.3d at 171.74; Rea, 627 F.3d at 938.41; Fiorani, 192 B.R. at 404-07; Pastore, 186 B.R. at 554-55; In re Martin, 2007 WL 2893431, at *1-5; In re Stinson, 285 B.R. at 241-50. 
from denying employment to, terminating the employment of, or discriminating with respect to employment against a person who is or has been a debtor, or who is or has been associated with a debtor, ${ }^{111}$ while $\S 525(\mathrm{~b})$ prohibits private employers from terminating the employment of, or discriminating with respect to employment against a person who is or has been a debtor, or who is or has been associated with a debtor. ${ }^{112}$ The prohibitions in both sections are the same, except $\S 525(\mathrm{~b})$ does not include the phrase "deny employment to."

The Supreme Court has said on multiple occasions, "[w]hen Congress includes particular language in one section of a statute, but omits it in another section of the same statute, it is generally presumed that Congress intention. ally omitted the language in the other section." 113 The United States Court of Appeals for the Eleventh Circuit relied on this canon of construction in Myers v. Toojay's Management. Corp., when it held that Congress deliberately omitted the "deny employment to" language from $§ 525(\mathrm{~b}) .{ }^{114}$ Myers went on to state that if Congress wanted to prohibit private employers from denying employment to debtors, it would have done so in the same way that it prohibited government employers from denying employment to debtors. ${ }^{115}$

The Supreme Court has also said on multiple occasions that "[w]hen identical words and phrases appear in the same statute, those words and phrases should be given the same meaning, ${ }^{116}$ and a statute should be interpreted to give effect to all of its provisions so that no part of it is rendered superfluous. ${ }^{117}$ The phrase "discriminate with respect to employment" appears in both $\S 525(\mathrm{a})$ and in $\S 525(\mathrm{~b})$. Because $\S 525(\mathrm{a})$ also prohibits government employers from "deny[ing] employment to" debtors, some courts have relied on this canon of construction to hold that the phrase "discriminate with respect to employment" cannot encompass hiring decisions because such an interpretation would render the phrase "deny employment to" in $\S 525(\mathrm{a})$ superfluous. ${ }^{118}$ In these courts' view, if the phrase "discriminate with respect to employment" in $\S 525(\mathrm{a})$ cannot encompass hiring decisions,

${ }^{111} 11$ U.S.C. $\$ 525(\mathrm{a})$.

${ }^{112} 11$ U.S.C. $\$ 525$ (b).

${ }^{113}$ Dean v. United States, 556 U.S. 568, 573 (2009); Clay v. United States, 537 U.S. 522, 528.29 (2003); Barnhart v. Sigmon Coal Co., 534 U.S. 438, 452 (2002); Russello v. United States, 464 U.S. 16, 23 (1983).

${ }^{114} 640$ F.3d 1278, 1285 (11th Cir. 2011) (citing Russello v. United States, 464 U.S. 16, 23 (1983)) ${ }^{115}$ Id.

${ }^{116}$ Henson v. Santander Consumer USA Inc., 137 S. Ct. 1718, 1720 (2017); Powerex Corp. v. Reliant Energy Servs., Inc., 551 U.S. 224, 232 (2007); IBP, Inc. v. Alvarez, 546 U.S. 21, 34 (2005); Sullivan v. Stroop, 496 U.S. 478, 484 (1990).

${ }^{117}$ Young v. United Parcel Serv., Inc., 135 S. Ct. 1338, 1352 (2015); Corley v. United States, 556 U.S 303, 314 (2009); TRW Inc. v. Andrews, 534 U.S. 19, 31 (2001); Duncan v. Walker, 533 U.S. 167, 174 (2001).

${ }^{118}$ Myers, 640 F.3d at 1285; In re Burnett, 635 F.3d at 172.73; Fiorani, 192 B.R. at 404-05. 
then the identical phrase in $\S 525$ (b) has to have the identical meaning. ${ }^{119}$ These courts also held that if the phrase "discriminate with respect to employment" in $\$ 525(\mathrm{a})$ is broad enough to encompasses hiring decisions, it would encompass termination decisions, and if that is true, then the phrase "terminate the employment of" in $\S 525(\mathrm{a})$ and in $\S 525(\mathrm{~b})$ would be superfluous. ${ }^{120}$ These courts interpret the phrase "discriminate with respect to employment" in $\S 525(\mathrm{a})$ and $\S 525(\mathrm{~b})$ as covering aspects of employment other than hiring and termination, such as the terms, conditions, and privileges of employment, and in these courts' opinion, the phrase has the same meaning in $\S 525(\mathrm{a})$ that it has in $\S 525(\mathrm{~b}) .121$

The purpose of the Bankruptcy Code is to give debtors a fresh start. ${ }^{122}$ Nonetheless, courts that consider private sector bankruptcy discrimination to be beyond the ambit of $\S 525(\mathrm{~b})$ do so because in their view, the plain text of the statute mandates that interpretation, and courts are required to interpret and apply statutes according to their terms, not according to congressional purposes. ${ }^{123}$

\section{B. The MinORity VieW is that 525(B) DOES APPLy to HiRING DECISIONS.}

The one court that has held that $\S 525(\mathrm{~b})$ does apply to hiring decisions did so based on the fresh start promise of the Bankruptcy Code. ${ }^{124}$ In Leary $v$. Warnaco, Inc., the United States District Court for the Southern District of New York held that although $\S 525(\mathrm{~b})$ does not contain the "deny employ. ment to" language that $\S 525$ (a) does, it would be absurd to read $\S 525$ (b) to allow private employers to refuse to hire debtors seeking to obtain the fresh start that bankruptcy is intended to afford, while prohibiting those same employers from discriminating against debtors who have already been hired. ${ }^{125}$

Leary further added that the "discriminate with respect to employment" language in $\S 525(\mathrm{~b})$ is capacious enough to cover hiring decisions because the phrase "discriminate with respect to employment" means all aspects of the employment relationship, including, hiring, termination, and the terms and conditions of employment. ${ }^{26}$ Leary concluded that the "evil" that $\S 525(\mathrm{~b})$ is intended to address is no different when an employer terminates

\footnotetext{
${ }^{119}$ Myers, 640 F.3d at 1285-86; In re Burnett, 635 F.3d at 172-73; Fiorani, 192 B.R. at 404-05.

${ }^{120}$ Myers, 640 F.3d at 1285-86; In re Burnett, 635 F.3d at 172-73; Fiorani, 192 B.R. at $404-05$.

${ }^{121}$ Myers, 640 F.3d at 1285-86; In re Burnett, 635 F.3d at 172-73; Fiorani, 192 B.R. at 404-05.

${ }^{122}$ Marrama v. Citizens Bank of Mass., 549 U.S. 365, 367 (2007).

${ }^{123}$ Myers, 640 F.3d at 1286; Burnett v. Stewart Title, Inc., 431 B.R. 894, 899-901 (S.D. Tex. 2010), affd, 635 F.3d 169, 171-74 (5th Cir. 2011); Fiorani, 192 B.R. at 405.07; In re Madison Madison, Int'l of IIl., P.C., 77 B.R. at $680-82$.

${ }^{124}$ Leary, 251 B.R. at 658.59 .

${ }^{125}$ Id.

${ }^{126}$ Id. at 659 .
} 
the employment of a debtor as contrasted with refusing to hire a debtor in the first instance; in either case, the fresh start purpose of bankruptcy is thwarted. ${ }^{127}$ Finally, Leary concluded that $\S 525(\mathrm{~b})$ does not contain the phrase "deny employment to" because "the scrivener was more verbose in writing $\S 525(\mathrm{a})$ than it was in writing $\S 525(\mathrm{~b}){ }^{1}{ }^{128}$

In terms of fulfilling the fresh start principle of the Bankruptcy Code, Leary's interpretation of $\S 525(\mathrm{~b})$ makes sense. In terms of applying estab. lished canons of statutory interpretation, however, the majority has the bet. ter of the argument. ${ }^{129}$ Additionally, Congress amended $\S 525$ on October 22, 1994, ${ }^{130}$ and again on April 20,2005, ${ }^{131}$ and in neither instance, did it add the phrase "deny employment to" to $\$ 525(\mathrm{~b})$. The Supreme Court has held that when courts reach a consensus on the meaning of a statute and Congress amends the statute without changing the relevant provision, this can be taken as persuasive evidence that Congress accepts the courts' interpretation. ${ }^{132}$ Finally, another court has observed that it is not unusual that Congress would restrain government employers in ways that it would not

${ }^{127} I d$. at 658 .

${ }^{128} I d$.

${ }^{129}$ For every canon employed to reach one conclusion, another canon can be employed to reach a different conclusion. In re Stinson, 285 B.R. at 248 n.11. For example, the canon that a statute cannot be applied beyond its text can be countered with the canon that to effect its purpose, a statute may be implemented beyond its text. Id. (citing Karl Llewellyn, Remarks on the Theory of Appellate Decision and the Rules or Canons About How Statutes are to be Construed, 3 VAND. L. REV. 395, 401-06 (1950)) "The canon that statutes in pari materia must be construed together is subject to the exception that statutes are not in pari materia if the scope and aim are distinct or where the design to depart from the general purpose or policy of the previous statute is apparent. The canon that if language is plain and unambiguous it must be given effect is countered by the desire to avoid literal interpretations if doing so leads to absurd results or thwarts the manifest purpose of the statute. ${ }^{n}$ In re Stinson, 285 B.R. at 248 n.11.

${ }^{130}$ Bankruptcy Reform Act of 1994, Pub. L. 103-394, Title III, $\$ 313,108$ Stat. 4106, 4131, 4140-41 (1994)).

${ }^{131}$ Bankruptcy Abuse Prevention and Consumer Protection Act of 2005, Pub. L. No. 109-8, Title XII, $\S 1211,119$ Stat. 23, 26, 192, 194 (2005).

${ }^{132}$ Manhattan Props., Inc. v. Irving Trust Co., 291 U.S. 320, 336 (1934) (stating that where the lower federal courts had reached a consensus interpretation of the Bankruptcy Act and Congress had amended the Act seven times without changing the relevant provision, this is persuasive evidence that Congress deemed the lower federal courts' interpretation of the Act acceptable). Judge Abner J. Mikva has a very different view of the doctrine of legislative acquiescence in judicial interpretation of statutes. See generally Abner J. Mikva, Reading and Writing Statutes, 48 U. PitT. L. REV. 627, 630 (1987). According to Judge Mikva, more than $40 \%$ of the members of Congress are lawyers, and most of them have practiced law, but when they take their oath of office, they stop reading advance sheets, law reviews, and trade journals. Id. at 630 . He also says that the members do not closely follow cases directly involving or interpreting statutes they have sponsored or in which they have an interest, and neither do the staff attorneys. Id. In Judge Mikva's view, if judicial review of statutes is to be meaningful and the primacy of Congress is to be maintained, there must be an increased awareness of what happens to a statute in the courts and in the agencies, and Congress must know what the courts treat as significant legislative history and how it is created. Id. Justice Stephen J. Markman of the Michigan Supreme Court shares Judge's Mikva's view and added, "[e]ven if Members of Congress were aware of all such cases, no sensible theory of statutory interpretation would require Congress to devote a substantial portion of its time to extinguishing judicial 
restrain private employers because the dynamics of the political decision making process differ when it comes to restricting the prerogatives of government employers versus private employers, namely, private employers probably have more effective and well-funded lobbyists to advocate against potential new causes of action against them than do governmental employers. ${ }^{133}$ In light of these principles, the fairest reading of $\S 525(\mathrm{~b})$ is that it does not prohibit private employers from denying employment to persons who are or have been debtors.

\section{BANKRUPTCY DISCRIMINATION MAY VIOLATE TITLE VII'S DISPARATE IMPACT PROHIBITION.}

Title VII of the Civil Rights Act of $1964^{134}$ prohibits employment discrimination on the basis of race, color, religion, sex, or national origin. ${ }^{135}$ The law prohibits intentional discrimination, which is known as disparate treatment, as well disparate impact, which describes employment practices that are not intentionally discriminatory, but nevertheless have a disproportionately adverse effect on persons because of their race, color, religion, sex, or national origin. ${ }^{136}$ In Title VII's original form, employers could only be found liable for disparate treatment. ${ }^{137}$ Disparate treatment occurs when an employer intentionally "treat[s] [a] person less favorably than others because of [race, color, religion, sex, or national origin]." ${ }^{138} \mathrm{~A}$ disparate treatment plaintiff bears the burden of proving the defendant intentionally discriminated against him or her on the basis of race, color, religion, sex, or national origin. ${ }^{139}$

In its first iteration, Title VII did not include an express prohibition on policies or practices that produce a disparate impact, but in Griggs v. Duke Power Co., the Supreme Court interpreted the law to prohibit facially neutral practices that operate in a discriminatory fashion. ${ }^{140}$ Griggs held that if an employment practice operates to exclude persons based on their race, color, religion, sex, or national origin, and the practice is not related to successful

forest fires." Stephen J. Markman, On Interpretation and Non-Interpretation, 3 BENCHMARK, 219, 226 n.60 (1987).

${ }^{133}$ (In re Martin), 2007 WL 2893431, at *2 n.10. For example, on August 31, 2007, Kansas Governor Kathleen Sebelius announced that all state agencies falling under the executive branch were barred from engaging in sexual orientation or gender identity discrimination, however, this mandate did not apply to private actors. Id. (citation omitted).

${ }^{134} 42$ U.S.C. $\$ 2000 e-2000 e \cdot 17$.

${ }^{135} 42$ U.S.C. $\$ 2000$ e-2(a)(1), (2).

${ }^{136}$ Ricci v. DeStefano, 557 U.S. 557, 577 (2009).

${ }^{137} I d$. at 577 (citing 42 U.S.C. $\$ 2000$-2(a)(1)).

${ }^{138} I d$. (quoting Watson v. Fort Worth Bank \& Trust, 487 U.S. 977, 985-86 (1988)).

${ }^{139} \mathrm{Id}$. (quoting Watson, 487 U.S. at 986).

${ }^{140} \mathrm{Griggs}$ v. Duke Power, Co., 401 U.S. 424, 431 (1971). 
job performance, the practice is prohibited. ${ }^{141}$ If, however, an employer demonstrates that the discriminatory practice is related to successful job perform: ance, the employer can continue to use the practice, unless a person challenging the practice can demonstrate that a legitimate alternative practice exists that is less discriminatory. ${ }^{142}$

On November 21, 1991, Congress enacted the Civil Rights Act of 1991, which among other things, codified Griggs. ${ }^{143}$ Under the Civil Rights Act of 1991, a plaintiff has to establish a prima facie case of disparate impact by demonstrating that an employer uses "a particular employment practice that causes a disparate impact on the basis of race, color, religion, sex, or national origin. ${ }^{1}{ }^{144}$ If the plaintiff establishes a prima facie case, the employer can defend itself by demonstrating that the practice is "job related for the position in question and consistent with business necessity." ${ }^{145}$ Even if, however, the employer proves job relatedness and business necessity, a plaintiff may still prevail by demonstrating that the employer refused to adopt an available alternative employment practice that has a less disparate impact and that serves its legitimate needs. ${ }^{146}$

Because blacks and Latinos are overrepresented among bankruptcy filers, they are probably disproportionately impacted by employers' refusal to hire debtors. ${ }^{147}$ Many, but certainly not all, commentators agree with this premise. ${ }^{148}$ There are no published-or unpublished for that matter-judicial

${ }^{141}$ Griggs, 401 U.S. at 431-35.

${ }^{142}$ Albemarle Paper Co. v. Moody, 422 U.S. 405, 425 (1975); Griggs, 401 U.S. at 432.

${ }^{143}$ Civil Rights Act of 1991 , Pub. L. No. 102-166, $\S \S 1,3$, Title I, $\S 105,105$ Stat. 1071, 1074-75 (1991) (codified as 42 U.S.C. $\$ \S 2000 \mathrm{e}-2(\mathrm{k})(1)(\mathrm{A}),(\mathrm{B}),(\mathrm{C}), 2000 \mathrm{e}-2(\mathrm{k})(2),(3)$ ).

${ }^{144} 42$ U.S.C. $\$ 2000 \mathrm{e} \cdot 2(\mathrm{k})(1)(\mathrm{A})(\mathrm{i})$.

${ }^{145} 42$ U.S.C. $\$ 2000 \mathrm{e}-2(\mathrm{k})(1)(\mathrm{A})(\mathrm{i})$.

${ }^{146} 42$ U.S.C. $\$ \S 2000 \mathrm{e}-2(\mathrm{k})(1)(\mathrm{A})(\mathrm{ii}) ; 2000 \mathrm{e}-2(\mathrm{k})(1)(\mathrm{C})$

${ }^{147}$ Concepción, supra note 8, at 526, 529-541; Earle, Madek \& Missirian, supra note 8, at 161-72; Karpa, supra note 8, at 86-90; Klein, Moore \& Moss, supra note 8, at *1-6; Landry \& Hardy, supra note 10, at 54-56; Shepard, supra note 8, at 1010-13, 1041-44.

${ }^{148}$ Concepción, supra note 8 , at 526,529-41 (According to a 2004 study by the Society of Human Resource Management, in 2003,35\% of employers used credit checks as an employment screening device. A credit check will disclose a bankruptcy. A 2000 study by the Federal Home Loan Mortgage Corporation found that $27 \%$ of whites had a poor credit rating, while $48 \%$ of blacks and $34 \%$ of Latinos had a poor credit rating. Since 1972, the Equal Employment Opportunity Commission has issued a number of deci. sions finding that the use of credit scores as an employment screening device has a disparate impact on racial minorities); Earle, Madek \& Missirian, supra note 8, at 161.72; Karpa, supra note 8, at 86.90 (Be. cause of lending discrimination known as "redlining," "blacks and Latinos have higher unemployment rates and less favorable credit scores," and as a consequence, they are more adversely impacted by the use of credit checks as an employment screening device"); Klein, Moore \& Moss, supra note 8, at *1.6 (There is a strong correlation between race and credit scores. Blacks have poor credit at a rate that is $21 \%$ higher than whites, and blacks file bankruptcy at disproportionate rates); Landry \& Hardy, supra note 10, at 54.60 ( Using bankruptcy status as a proxy for [ ] hiring decisions may give rise to disparate impact claims [under Title VII of the Civil Rights Act of 1964.] The [Equal Employment Opportunity Commission] expressly recommends [that employers abstain from using bankruptcy status as a pre-employment screening device unless bankruptcy status is] essential to the position." Ultimately, however, the authors con- 
decisions that address the question of whether private employers' refusal to hire debtors has a disparate impact on blacks and Latinos. There are, how. ever, two high profile cases that the Equal Opportunity Employment Commission ("EEOC") ${ }^{149}$ filed where the agency claimed that employers" use of credit history checks violated Title VII's prohibition on disparate impact. ${ }^{150}$ The EEOC lost both cases in spectacular fashion, and neither loss had anything to do the merits of the disparate impact claims. ${ }^{151}$

In EEOC v. Freeman and EEOC v. Kaplan Higher Education Corp., the EEOC challenged two private employers' use of credit history checks in screening employment applicants. ${ }^{152}$ In both cases, the EEOC used Kevin Murphy ("Dr. Murphy"), an industrial and organizational psychologist to produce statistical data showing that the employers' use of credit history checks had an unlawful disparate impact on black applicants. ${ }^{153}$ In both cases, the trial courts deemed Dr. Murphy's report and testimony so unreliable that the courts excluded both and granted the employers' motions for summary judgment. ${ }^{154}$ The United States Courts of Appeals for the Fourth and Sixth Circuits not only affirmed the district courts' summary judgment orders, both courts chastised the EEOC for its litigation strategy, particularly its use of Dr. Murphy. ${ }^{155}$

At least two reasons might explain why there is no reported litigation on

clude that employers should be allowed to use bankruptcy status in making employment decisions); Shepard, supra note 8, at 1010-13, 1041-44 (racial minorities are more likely than whites to have low credit scores and are more likely to suffer the adverse effects of the use of credit scores in employment screening). But see Phillips \& Schein, supra note 10, at 156 ("While often alleged by opponents of the use of credit reports, the anecdotal evidence suggests that minorities are not necessarily disadvantaged by the use of credit reports.").

${ }^{149}$ The EEOC is "responsib[le] for developing and implementing agreements, policies[,] and practices designed to maximize effort, promote efficiency, and eliminate conflict, competition, duplication[,] and inconsistency among the operations, functions[,] and jurisdictions of the various departments, agencies[,] and branches of the Federal Government responsible for the implementation and enforcement of equal employment opportunity legislation, orders, and policies." 42 U.S.C. $\$ 2000 e \cdot 14$.

${ }^{150}$ EEOC v. Freeman, 778 F.3d 463, 464-68 (4th Cir. 2015); EEOC v. Kaplan Higher Educ. Corp., 748 F.3d 749, 750-54 (6th Cir. 2014). In Parker v. CB Richard Ellis Hawaii, Inc., the district court dismissed the plaintiffs claim that the employer's use of credit history checks caused an unlawful disparate impact on blacks because it found that personal creditworthiness was related to the responsibilities of the job of associate accountant, which is the job the plaintiff sought. No. CV 09-00574 DAE LEK, 2010 WL 5388362, at *9-11 (D. Haw. Dec. 21, 2010). The plaintiff also admitted that he did not have any statistical evidence that the employer's use of credit history checks caused a disparate impact based on race. Parker, 2010 WL 5388362, at *11. Likewise, in Freeman v. Atlantic Refining E' Marketing, Corp., the district court dismissed the plaintiff's claim that the employer's use of credit reports caused a disparate impact based on race because the plaintiff admitted that he had no statistical evidence of disparate impact. No. 92 . 7029, 1994 WL 156723, at *8-9 (E.D. Pa. Apr. 28, 1994).

${ }^{191}$ Freeman, 778 F.3d at 464.68 ; Kaplan, 748 F.3d at $750-54$.

${ }^{152} I d$.

${ }^{153} \mathrm{Id}$.

${ }^{154}$ Id.

${ }^{159}$ Id. 
the issue of private employers' refusal to hire debtors causing a disparate impact based on race. First, a person cannot successfully argue that an em. ployment practice causes a disparate impact based on his or her case alone because disparate impact requires proof that the challenged employment practice discriminates against a group based on race, color, religion, sex, or national original, not just on an individual. ${ }^{156}$ That means a single plaintiff cannot succeed unless he or she can amass statistics that demonstrate that not only was he or she excluded, but others similarly situated were excluded because of the same employment practice. ${ }^{157}$ Although employers that are covered by Title VII ${ }^{158}$ are required to maintain records that disclose the impact their selection procedures have on the employment opportunities of persons by race, sex, or ethnic group, ${ }^{159}$ it is expensive to obtain this information and have it analyzed by a person with the requisite expertise to pass judicial muster. There are not a lot of plaintiffs with the financial wherewithal to fund disparate impact litigation, and there are not a lot of lawyers who can afford to fund these cases themselves on the chance that they will result in a large enough recovery that the lawyer can recoup the costs he or she advanced. A second possible reason why there is no reported litigation on the issue of private employers' refusal to hire debtors causing a disparate impact based on race is judicial solicitude towards employers in discrimination cases.

Since the Supreme Court's decision in Wards Cove Packing Co. v. Atonio, ${ }^{160}$ the federal judiciary has been quite deferential towards employers when it comes to evaluating the legitimacy of their justifications for their employment practices. ${ }^{161}$ The United States Court of Appeals for the Eighth

${ }^{156} 42$ U.S.C. $\$ \S 2000 \mathrm{e}-2(\mathrm{k})(1)(\mathrm{A})(\mathrm{i})$, (ii); 29 C.F.R. $\S 1607.4(\mathrm{D})$.

${ }^{157}$ Watson v. Fort Worth Bank \& Trust, 487 U.S. $977,993-1000$ (1988).

${ }^{158}$ An "employer" covered by Title VII means "a person engaged in an industry affecting commerce who has fifteen or more employees for each working day in each of twenty or more calendar weeks in the current or preceding calendar year, and any agent of such a person." 42 U.S.C. $\$ 2000$ e(b). This definition excludes: "(1) the United States, a corporation wholly owned by the Government of the United States, an Indian tribe, or any department or agency of the District of Columbia subject by statute to procedures of the competitive service (as defined in section 2102 of Title 5), or (2) a bona fide private membership club (other than a labor organization) [that] is exempt from taxation under section 501(c) of Title 26." 42 U.S.C. $\$ 2000$ e(b).

${ }^{159} 29$ C.F.R. $\$ \S 1607.4(A),(B)$.

${ }^{160} 490$ U.S. $642,645-661$ (1989).

${ }^{161}$ In the Civil Rights Act of 1991, Congress said Wards Cove "weakened the scope and effectiveness of civil rights protections[,] and legislation [was] necessary to provide additional protections against unlawful discrimination in employment." Pub. L. No. 102-166, §§ 2(2), 2(3), 105 Stat. 1071 (1991). One of the purposes of the 1991 law was "to respond to recent decisions of the Supreme Court by expanding the scope of relevant civil rights statutes in order to provide adequate protection to victims of discrimination." Id. at \$3(4); Kevin M. Clermont \& Stewart J. Schwab, Employment Discrimination Plaintiffs in Federal Court: From Bad to Worse?, 3 Harv. L. \& PoL'y Rev. 103, 104-05, 109-15, 127-32 (2009) (An empirical study of employment discrimination cases litigated in federal court between 1979 and 2006 led the authors to conclude that "federal courts disfavor employment discrimination plaintiffs," and would-be-plaintiffs file fewer cases because of the "fear of judicial bias at the district court level and the appellate court level." 
Circuit often says in employment discrimination cases that "courts do not sit as super-personnel departments reviewing the wisdom or fairness of the business judgments made by employers." ${ }^{\text {162 }}$

From the publicly available data, no court has been presented with the question of whether employers' refusal to hire debtors causes a disparate impact based on race. On the related issue of the use of credit history checks more broadly, the EEOC botched Freeman and Parker. Thus, one will have to wait for another day to see how a court will rule in a case that squarely presents the question of whether bankruptcy discrimination causes a disparate impact based on race, national origin, or both.

\section{MOST AMERICANS EXIST IN A STATE OF FINANCIAL PERIL AND OVERSPENDING HAS LITTLE TO DO WITH IT.}

There is a view that debtors are irresponsible, dishonest, have poor judg. ment, poor management skills, or both, or that they are more susceptible to illicit temptation because of financial pressure, therefore, "bankruptcy status [is] a valuable screening tool in some hiring contexts." ${ }^{163}$ One cannot help but wonder whether this view is partially predicated on the notion that opportunities for advancement should be reserved for those who have been vir-

The study showed that "[employment discrimination] cases [end] less favorably for plaintiffs than other kinds of cases, [and] [p]laintiffs who appeal their losses or [have to defend their victories on appeal] fare remarkably poorly in the circuit courts." Between 1979 and 2006, employment discrimination plaintiffs prevailed in $15 \%$ of cases, plaintiffs in other kind of cases prevailed in $51 \%$ of cases, and "appellate courts reversed plaintiffs' wins far more often than defendants' wins.")

${ }^{162}$ Hutson v. McDonnell Douglas Corp., 63 F.3d 771, 781 (8th Cir. 1995). The United States Court of Appeals for the Sixth Circuit takes a different approach. In White v. Baxter Healthcare Corp., the Sixth Circuit stated:

Contrary to what Judge Gilman maintains, our Circuit has never adopted a "business-judgment rule" which requires us to defer to the employer's "reasonable business judgment ${ }^{n}$ in Title VII cases. Indeed, in most Title VII cases the very issue in dispute is whether the employer's adverse employment decision resulted from an objectively unreasonable business judgment, i.e., a judgment that was based upon an impermissible consideration such as the adversely-affected employee's race, gender, religion, or national origin. In determining whether the plaintiff has produced enough evidence to cast doubt upon the employer's explanation for its decision, we cannot, as Judge Gilman does, unquestionably accept the employer's own self-serv. ing claim that the decision resulted from an exercise of "reasonable business judg. ment." Nor can we decide "as a matter of law" that "an employer's proffered justification is reasonable." The question of whether the employer's judgment was reasonable or was instead motivated by improper considerations is for the jury to consider. Our role is merely to assess whether the plaintiff has presented enough evidence for a reasonable jury to accept the plaintiffs claim that the employer made an unlawful business decision.

533 F.3d 381, 393 n.6 (6th Cir. 2008) (internal citations omitted) (emphasis in original).

${ }^{163}$ Landry \& Hardy, supra note 10, at 57.60; Phillips \& Schein, supra note 10, at 152-57. 
tuous, and one sign of virtue is a pristine financial record. According to this view, those who have spotty financial records have not been sufficiently virtuous, therefore, they should not be heard to complain about being denied employment opportunities because those are the just deserts for persons who are undeserving in the first place. Professor Michael Sandel described this attitude as "the smug assumption that ... success is the crown of virtue," and that those who are on the top of the social, educational, political, or economic hierarchy are on top because they are more deserving than those below. ${ }^{164}$ Commenting on this kind of thinking in the context of admission to highly selective colleges and universities, Professor Randall Kennedy has written,

$[\mathrm{m}]$ any of the traits we most admire - intelligence, knowledge, creativity, insight - are not solely, often not even mainly, the fruit of our own effort[,] but are instead offshoots of circumstances beyond one's control: inborn genius, health, caring parents, attentive teachers, a decent neighborhood. That is why discussions of university admissions and similar mechanisms of allocation need to be scrubbed clean of the excessively self-congratulatory individualism in which they tend to be steeped. ${ }^{165}$

Putting philosophical quarrels aside for a moment, there is some empirical data that undermines the premise that an adverse inference about a person's character or fitness as an employee is merited simply because the person is or has been a debtor. ${ }^{166}$

In 2004, Professor Elizabeth Warren published an article entitled, The Economics of Race: When Making It to the Middle Is Not Enough, in which she discussed her and her colleagues' findings from the 2001 Consumer Bankruptcy Project ("CBP").167 According to Professor Warren, in 1981 when she and her colleagues started their first study of families that had filed bank-

\footnotetext{
${ }^{164}$ Michael J. Sandel, Justice: What's the Right Thing to Do? 178 (Farrar, Straus and Giroux 2009); Randall Kennedy, For Discrimination: Race, Affirmative Action, and the Law $112 \cdot 13$ (Pantheon Books 2013).

${ }^{165}$ Kennedy, supra note 163 , at 113 .

${ }^{166}$ Atkinson, supra note 15 , at $1059-60$ (discussing a 2011 settlement between the United States Department of Justice ("DOJ") and Countrywide Financial Corporation over the bank's racially discriminatory lending practices; a 2012 settlement between the DOJ and Sun Trust Mortgage over the lender's racially discriminatory lending practices; a 2012 settlement between the DOJ and Wells Fargo over the banks' racially discriminatory lending practices; and a 2013 settlement between the Consumer Financial Protection Bureau, the DOJ, and PNC Bank over the bank's racially discriminatory lending practices); Warren, supra note 15, at 1780-81 (discussing the 2001 Consumer Bankruptcy Project, which showed racial disparities in bankruptcy filings and that ${ }^{4} 90 \%$ of bankruptcy filers either attended college, had a job in the upper $80 \%$ of all occupations in the United States, or owned a home, $67 \%$ met two of these criteria, and nearly $30 \%$ met all three.")

${ }^{167}$ Warren, supra note 15 , at 1777.99 .
} 
ruptcy, they expected to find debtors who were marginally employed if at all, poorly educated, and facing a bleak financial future. ${ }^{168}$ Their predictions about their subjects' financial situation was not far off the mark, as their 1981 study showed that "approximately $25 \%$ of the families filing for bankruptcy had incomes below the poverty line, and 50\% had incomes between the pov. erty line and the national median income." 169

By the time of the publication of the CBP in 2001, however, things had changed dramatically. ${ }^{170}$ The CBP showed that "90\% of debtors either attended college, had a job in the upper $80 \%$ of all occupations in the United States, or owned a home; $67 \%$ fit into two of these categories; and nearly $30 \%$ fit into all three." ${ }^{171}$ This led Professor ${ }^{172}$ Warren to describe the bankruptcy courts as

[places] where middle class families in extraordinary distress seek relief . . Bankruptcy is a middle class phenomenon, a place of escape for those who have good jobs, established credit, accumulated assets, and [who] have suffered sharp reversals. . Those in bankruptcy are disproportionately middle class when measured by education, occupation, and home ownership. ${ }^{173}$

Warren further noted that the CBP showed that " $68.3 \%$ of all bankruptcy filings resulted from job layoffs, job cutbacks, salary cuts, or business failings." 174 "Medical problems and medical debts accounted for $51 \%$ of filings, and divorce or the death of a spouse accounted for $20 \%$ of filings." ${ }^{175}$ All told, "job difficulties, medical issues, and divorce played a role in $90 \%$ of bankruptcy filings according to the CBP. ${ }^{176}$ The CBP also revealed that there is a racial dimension to who files bankruptcy. ${ }^{177}$ "Black families filed at the rate of 29.6 filings per 1,000 households; Latino families filed at the rate of 17.1 filings per 1,000 households; and white families filed at the rate of 9.3 filings per 1,000 households, meaning black families are more than three times as likely to file bankruptcy as white families, and Latino families are almost

\footnotetext{
${ }^{168}$ Id. at 1780 .

${ }^{169} I d$.

${ }^{170} \mathrm{Id}$.

${ }^{171} I d$.

${ }^{172}$ In 2012, Professor Elizabeth Warren became United States Senator Elizabeth Warren, representing the Commonwealth of Massachusetts. Biographical Directory of the United States Congress 1774 - Present, http://bioguide.congress.gov/biosearch.asp (last visited July 26, 2017).

${ }^{173}$ Warren, supra note 15 , at 1799.

${ }^{174}$ Id. at 1777,1784 .

${ }^{175}$ Id. at 1784 .

${ }^{176}$ Id. at 1777,1784 .

${ }^{177}$ Warren, supra note 15 , at 1777,1786 .
} 
twice as likely to file bankruptcy as white families."178

Professor Warren's Economics of Race article demonstrates that most of those who seek bankruptcy protection are middle class, regardless of race, but middle class blacks and Latinos exist under far more financial risk than do middle class whites. ${ }^{179}$ For example, Warren contends that home ownership is widely considered a hallmark of middle class financial stability. ${ }^{180}$ Analyz, ing data from 2001, she found that "67.7\% of Americans owned their homes, and those homes had an average value of $\$ 122,000 .{ }^{n 181}$ That data, however, showed marked racial disparities in home ownership rates and home values. ${ }^{182}$ It showed that "whites owned homes at a rate of $74.3 \%$; blacks owned homes at a rate of $47.7 \%$; and Latinos owned homes at a rate of $47.3 \%$."183 It also revealed that "white homeowners' homes had a median value of $\$ 130,000$, while the median value of the homes owned by non-white persons was $\$ 92,000$." 184

Owning a home is typically associated with middle class financial stability, but being a homeowner does not immunize one from the kind of fiscal distress that can lead to a bankruptcy filing, and here too, the CBP showed racial disparities among homeowners who filed bankruptcy. ${ }^{185}$ The data demonstrated that "black homeowners file bankruptcy at the rate of 31.7 per 1,000 homeowners; Latinos file at the rate of 16.4 per 1,000 homeowners; and whites file at the rate of 6.1 per 1,000 homeowners." ${ }^{186}$ Stated another way, "black homeowners file at a rate that is more than five times higher than the rate at which white homeowners file, and Latino homeowners file at a rate that is more than three times higher than the rate at which white homeowners file." 187 One reason why black and Latino homeowners exist in a more perilous financial state than their white counterparts is racially discriminatory lending practices in credit and housing transactions. ${ }^{188}$

On April 11, 1968, Congress enacted the Fair Housing Act ("FHA"), which makes it unlawful to discriminate in the sale or rental of housing because of race, color, religion, sex, familial status, or national origin. ${ }^{189}$ On Oc-

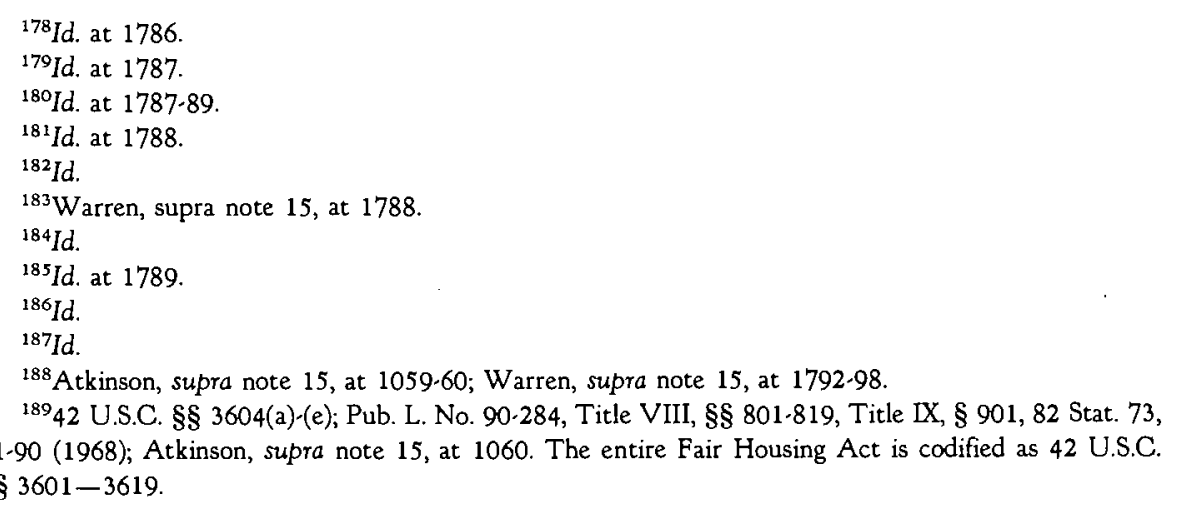


tober 28, 1974, Congress enacted the Equal Credit Opportunity Act ("ECOA"), which makes it unlawful for any creditor to discriminate against any applicant for credit on the basis of race, color, religion, national origin, sex, marital status, or age. ${ }^{190}$ Notwithstanding the FHA and the ECOA, blacks and Latinos have been disproportionately subjected to discrimination in credit and housing transactions. ${ }^{191}$

In 2015, Professor Abbye Atkinson published an article entitled Modify. ing Mortgage Discrimination in Consumer Bankruptcy, in which she discussed a number of cases filed by the United States Department of Justice ("DOJ") against various entities for engaging in racially discriminatory consumer lend. ing. ${ }^{192}$ In one such case, the DOJ sued Countrywide Financial Corporation, Countrywide Home Loans, Inc., and Countrywide Bank ("Countrywide") on December 21, 2011, which at that point was the largest fair lending lawsuit the DOJ ever filed. 193

The DOJ's complaint alleged "that between 2004 and 2008, Country. wide discriminated by charging more than 200,000 [Latino] and [black] borrowers in more than 180 geographic markets in 41 states and the District of Columbia higher fees and rates than non-Hispanic White borrowers because of their race or national origin rather than the borrowers' creditworthiness or other objective criteria related to borrower risk. ${ }^{{ }^{194}}$ The DOJ also asserted that "Countrywide [ ] discriminated by steering more than 10,000 [Latino] and [black] borrowers into subprime mortgages when non-Hispanic White borrowers with similar credit profiles received prime loans." ${ }^{195}$ On June 22, 2015 , Countrywide paid $\$ 335$ million to settle the case. ${ }^{196}$

\footnotetext{
${ }^{190} 15$ U.S.C. $\$ 1691(a)(1)$; Pub. L. No. $93-495$, Title VII, $\$ \S 701.737$, 88 Stat. $1500,1521.1525$ (1974); Atkinson, supra note 15, at 1060. The entire Equal Credit Opportunity Act is codified as 15 U.S.C. $\$ \S 1691$ - 1691 f.

${ }^{191}$ Atkinson, supra note 15 , at 1059-60; Warren, supra note 15, at 1792-98.

${ }^{192}$ Atkinson, supra note 15 , at 1059-61.

${ }^{193}$ Id. at 1059; Complaint Overview in United States v. Countrywide Financial Corporation, et al. (C.D. Cal.), https://www.justice.gov/sites/default/files/crt/legacy/2012/04/11/countrywide_complaint _overview.pdf (last visited May 10, 2016); Complaint - United States v. Countrywide Financial Corporation, et al. (C.D. Cal.), https://www.justice.gov/sites/default/files/crt/legacy/2011/12/21/country widecomp.pdf (last visited May 10, 2016).

${ }^{194}$ Atkinson, supra note 15, at 1059; Complaint Overview in United States v. Countrywide Financial Corporation, et al. (C.D. Cal.), https://www.justice.gov/sites/default/files/crt/legacy/2012/04/11/coun trywide_complaint_overview.pdf (last visited May 10, 2016); Complaint - United States v. Countrywide Financial Corporation, et al. (C.D. Cal.), https://www.justice.gov/sites/default/files/crt/legacy/2011/12/ 21/countrywidecomp.pdf (last visited May 10, 2016).

${ }^{195}$ Atkinson, supra note 15, at 1059; Complaint Overview in United States v. Countrywide Financial Corporation, et al. (C.D. Cal.), https://www.justice.gov/sites/default/files/crt/legacy/2012/04/11/coun trywide_complaint_overview.pdf (last visited May 10, 2016); Complaint - United States v. Countrywide Financial Corporation, et al. (C.D. Cal.), https://www.justice.gov/sites/default/files/crt/legacy/2011/12/ 21/countrywidecomp.pdf (last visited May 10, 2016).

${ }^{196}$ Atkinson, supra note 15, at 1059; DOJ/Countrywide Settlement Information - USAO-CDCA -
} 
The next case Professor Atkinson discussed involved a May 31, 2012 consent order between the DOJ and SunTrust Mortgage, Inc. ("SunTrust") to settle a case the DOJ filed alleging that SunTrust "engaged in a pattern or practice of discrimination that increased loan prices for many of the qualified [black] and [Latino] borrowers who obtained loans between 2005 and 2009." 197 The DOJ also alleged "that SunTrust routinely charged black and Latino borrowers higher discretionary broker fees and retail loan markup fees." ${ }^{198}$ SunTrust paid $\$ 21$ million to settle the case. ${ }^{199}$

Professor Atkinson then turned to a case the DOJ filed on July 12, 2012 against Wells Fargo, which at that point was the DOJ's second largest fair lending lawsuit ever. ${ }^{200}$ The DOJ alleged that "Wells Fargo steered black and Latino homebuyers into expensive mortgages and charged them excessive fees." ${ }^{201}$ Wells Fargo paid $\$ 175$ million to settle the case. ${ }^{202}$

Finally, Professor Atkinson discussed a January 9, 2014 settlement between the Consumer Financial Protection Bureau of the United States ("CFPB") and National City Bank, which was a lending discrimination law. suit where the CFPB alleged that "National City Bank had policies and practices in place that resulted in black and Latino borrowers paying higher interest rates, fees, and other costs than similarly situated white borrowers, and that those higher rates, fees, and costs could not be fully explained by factors other than race and national origin." ${ }^{203}$ National City Bank paid \$35 million to settle the case. ${ }^{204}$

Professor Atkinson's article also highlighted the disparate racial impact of the 2008 housing market collapse and recession. ${ }^{205}$ At the apex of the sub-

Department of Justice, https://www.justice.gov/usao-cdca/dojcountrywide-settlement-information (last visited May 10, 2016).

${ }^{197}$ Atkinson, supra note 15, at 1059; Justice Department Reaches \$21 Million Settlement to Resolve Allegations of Lending Discrimination by Suntrust Mortgage - OPA - Department of Justice, bttps:// www.justice.gov/opa/pr/justice-department-reaches-21-million-settlement-resolve-allegations-lending-dis crimination (last visited May 10, 2016).

${ }^{198}$ Atkinson, supra note 15, at 1059; Justice Department Reaches \$21 Million Settlement to Resolve Allegations of Lending Discrimination by Suntrust Mortgage - OPA - Department of Justice, https:// www.justice.gov/opa/pr/justice-department-reaches-21-million-settlement-resolve-allegations-lending-dis crimination (last visited May 10, 2016).

${ }^{199} I d$.

${ }^{200}$ Atkinson, supra note 15, at 1059; Justice Department Reaches Settlement with Wells Fargo Result. ing in More Than $\$ 175$ Million in Relief for Homeowners to Resolve Fair Lending Claims - OPA Department of Justice, https://www.justice.gov/opa/pr/justice-department-reaches-settlement-wells-fargo -resulting-more-175-million-relief (last visited May 11, 2016)

${ }^{201} I d$.

${ }^{202} I d$.

${ }^{203}$ Atkinson, supra note 15, at 1059-60; CFPB and USA v National City Bank Consent Order -nationalcitybanksettle.pdf, https://www.justice.gov/sites/default/files/crt/legacy/2014/04/08/nationalcity banksettle.pdf (last visited May 11, 2016).

${ }^{204}$ Id.

${ }^{205}$ Atkinson, supra note 15 , at 1065-67. 
prime mortgage mania that preceded the 2008 recession, "black women were $5.7 \%$ more likely to receive a subprime mortgage than black men and $256 \%$ more likely to receive a subprime mortgage than white men." 206 "Latino women were $12.7 \%$ more likely to receive a subprime mortgage than Latino men and $177 \%$ more likely to receive a subprime mortgage than white men." ${ }^{207}$ Professor Atkinson analyzed a 2014 study that showed that of the top 100 cities that were home to the highest number of homeowners whose homes were worth less than the debt that encumbered those homes, 71 of those cities had a population that exceeded $40 \%$ black and Latino. ${ }^{208}$

Atkinson also analyzed a study of home foreclosures between 2007 and 2009, which demonstrated that "black and Latino homeowners were $70 \%$ more likely to lose their homes to foreclosure than white homeowners, and higher income blacks were more than $80 \%$ more likely to lose their homes to foreclosure than similarly situated whites. ${ }^{\text {209 }}$

Housing is not the only area in which Professor Atkinson found that blacks and Latinos face economic headwinds. ${ }^{210}$ She analyzed a 1995 study showing that automobile sellers "routinely charged blacks and women higher prices for cars than white male purchasers." ${ }^{211}$ She found a later study that examined "more than 300,000 car loans across 33 states, and it showed that blacks paid more for cars than white purchasers regardless of creditworthiness. ${ }^{212}$ She then turned to a December 20, 2013 settlement between the DOJ, the CFPB, and Ally Bank, which at that point was the largest auto loan discrimination settlement in history. ${ }^{213}$ The DOJ and the CFPB alleged that Ally Bank "discriminated by charging approximately 235,000 black, Latino, and Asian-Pacific Islander borrowers higher interest rates than white borrowers." ${ }^{214}$ The agencies claimed that "Ally Bank charged borrowers higher interest rates because of their race or national origin, and not because of their creditworthiness or other objective criteria related to borrower risk, and that the average victim paid between $\$ 200$ and $\$ 300$ extra during the term of his or her loan. ${ }^{215}$ Ally Bank paid $\$ 98$ million to settle the case. ${ }^{216}$

\footnotetext{
${ }^{206}$ Id. at 1065 .

${ }^{207}$ Id.

${ }^{208}$ Id. at 1066 .

${ }^{209} \mathrm{Id}$.

${ }^{210}$ Atkinson, supra note 15 , at $1066-67$.

${ }^{211} I d$.

${ }^{212} I d$.

${ }^{213}$ Atkinson, supra note 15, at 1067; Justice Department and Consumer Financial Protection Bureau Reach $\$ 98$ Million Settlement to Resolve Allegations of Auto Lending Discrimination by Ally - OPA - Department of Justice, https://www.justice.gov/opa/pr/justice-department-and-consumer-financialprotection-bureau-reach-98-million-settlementto (last visited May 11, 2016).

${ }^{214} I d$.

${ }^{215} \mathrm{Id}$.

${ }^{216} \mathrm{Id}$.
} 
Ally Bank, however, was not the sole lender engaging in racially discriminatory auto lending. ${ }^{217}$ On July 14, 2015, the DOJ sued American Honda Finance Corporation ("AHFC") alleging that "AHFC discriminated by charging thousands of black, Latino, and Asian-Pacific Islander borrowers higher interest rates than white borrowers." ${ }^{218}$ The DOJ and the CFPB claimed that "AHFC charged borrowers higher interest rates because of their race or national origin, and not because of their creditworthiness or other objective criteria related to borrower risk." 219 The DOJ's complaint also alleged that the "average black borrower paid over $\$ 250$ more during the term of his or her loan because of discrimination, the average Latino borrower paid over $\$ 200$ more during the term of his or her loan because of discrimination, and the average Asian-Pacific Islander borrower paid over $\$ 150$ more during the term of his or her loan because of discrimination." 220 AHFC paid \$24 million to settle the case. ${ }^{221}$

Despite the existence of the FHA and the ECOA, blacks and Latinos face many daunting and irrational obstacles in conducting ordinary consumer transactions such as purchasing homes and cars. ${ }^{222}$ But discriminatory and predatory lending practices are not the only challenges blacks and Latinos face in their attempt to obtain and maintain economic security. Professor Atkinson analyzed census data, and it showed that in 2010, "black households had a median income of $\$ 32,068$, Latino households had a median income of $\$ 37,579$, and white households had a median income of $\$ 54,620$."223 She cited a 2011 article demonstrating that "the median income for black Americans has remained at approximately $60 \%$ of the median income for white Americans for the past four decades." ${ }^{224}$ The economic recession of 2008 and its aftermath exacerbated the racial income gap. ${ }^{225}$ Atkinson cited data showing that "between 2010 and 2013, the median income for nonwhite Americans decreased by $9 \%$, while the median income for white Americans decreased by 1\%, and between 1984 and 2009, whites enjoyed an in-

\footnotetext{
${ }^{217}$ Atkinson, supra note 15 , at 1067.

${ }^{218}$ Id.; https://www.justice.gov/opa/file/629806/download (last visited May 11, 2016).

${ }^{219}$ Atkinson, supra note 15, at 1067; Justice Department and Consumer Financial Protection Bureau Reach Groundbreaking Settlement to Resolve Allegations of Auto Lending Discrimination by Honda OPA - Department of Justice, https:/www.justice.gov/opa/pr/justice-department-and-consumer-finan cial-protection-bureau-reach-groundbreaking-settlement (last visited May 11, 2016).

${ }^{220}$ Atkinson, supra note 15, at 1067; Justice Department and Consumer Financial Protection Bureau Reach Groundbreaking Settlement to Resolve Allegations of Auto Lending Discrimination by Honda OPA -Department of Justice, https://www.justice.gov/opa/pr/justice-department-and-consumer-finan cial-protection-bureau-reach-groundbreaking-settlement (last visited May 11, 2016).

${ }^{221} I d$.

${ }^{222}$ Atkinson, supra note 15, at 1059-60; Warren, supra note 15 , at $1792-98$.

${ }^{223}$ Atkinson, supra note 15 , at 1062.

${ }^{224} I d$.

${ }^{225}$ Id. at $1062-63$.
} 
crease in wealth of $\$ 5.19$ for every $\$ 1$ increase in average income compared to an increase of a mere $\$ .69$ for every $\$ 1$ increase in average income for blacks." 226

Atkinson also evidenced that in addition to there being a racial income gap in the United States, there is a racial wealth gap. ${ }^{227}$ Wealth is a more accurate way to gauge financial security than income because "wealth is seen first as a personal safety net, or an unspecified amount of money that is stored away to cushion against the unexpected health crisis, job termination, legal difficulty, or repair of the family car." ${ }^{228}$ Using data from a 2006 article that Professor Thomas M. Shapiro wrote entitled Race, Homeownership and Wealth, Professor Atkinson stated that adjusted for 1999 dollars, the "net wealth of the parents of the typical black family was $\$ 46,000$, compared to $\$ 200,000$ for the parents of the typical white family." 229 This same data showed that "the total wealth gap between white families and black families increased from $\$ 85,000$ in 1984 to $\$ 236,500$ in 2009." 230 Professor Atkinson states that "[i]n 2013, white households had a median net worth of $\$ 141,900$; Latino households had a median net worth of $\$ 13,700$; and black households had a median net worth of $\$ 11,000 .{ }^{\prime 231}$ Put another way, the median white household had 12.9 times more net worth than the median black household and 10.36 times more net worth than the median Latino household. ${ }^{232}$ In the three years before the 2008 recession and the year following it, Latinos lost $66 \%$ of their net worth, blacks lost $53 \%$ of their net worth, and whites lost $16 \%$ of their net worth. ${ }^{233}$

Simply put, blacks and Latinos have a demonstrably more difficult time obtaining and maintaining wealth than their similarly situated white counterparts, and this contributes to blacks being more than three times more likely than similarly situated whites to file bankruptcy and Latinos being almost twice as likely as similarly situated whites to file bankruptcy. ${ }^{234}$

Race notwithstanding, studies show that if nearly one-half of American adults encountered an emergency that required $\$ 2,000$ to address, they could not come up that amount within thirty days. ${ }^{235}$ Instead, members of this

\footnotetext{
${ }^{226} I$ d.

${ }^{227}$ Id. at $1062 \cdot 64$.

${ }^{228}$ Atkinson, supra note 15 , at 1062.63 (quoting Thomas M. Shapiro, Race, Homeownership and Wealth, 20 WASH. U. J.L. \& POL'Y 53, 57 (2006)).

${ }^{229}$ Id. at 1063.

${ }^{230}$ Id. at 1064 .

${ }^{231} I d$.

${ }^{232} I d$.

${ }^{233} \mathrm{Id}$. Professor Atkinson noted the cruel irony that attends the difficulty that black Americans face in obtaining and maintaining wealth, and that is, at one point during the mid-nineteenth century, slaves accounted for approximately $20 \%$ of the wealth held by Americans. Id. at 1063 .

${ }^{234}$ Atkinson, supra note 15 , at $1073-75$; Warren, supra note 15 , at 1786 .

${ }^{235}$ Mehrsa Baradaran, It's Time for Postal Banking, 127 Harv. L. Rev. F. 165, 166 (2014).
} 
cohort would have to resort to "payday lenders, check cashers, and other fringe banking institutions." 236 "Almost 88 million people in the United States are 'unbanked' 237 or 'underbanked," 238 and these persons also rely on fringe banking institutions for their banking or credit needs. ${ }^{239}$

In May 2015, the Board of Governors of the Federal Reserve System published a "Report on the Economic Well-Being of U.S. Households in 2014 ("Fed Report")." ${ }^{240}$ The Fed Report revealed that 47\% of Americans could not easily come up with $\$ 400$ to cover an emergency. ${ }^{241}$ Fourteen percent could not come up with that amount at all; $10 \%$ would have to sell something to raise that amount; $18 \%$ would have to use a credit card that they could not pay in full at the next billing cycle; $13 \%$ would have to borrow from friends or family; and $2 \%$ would have to use a payday loan. ${ }^{242}$

One member of this " $\$ 400$ Club" is Neal Gabler, an author and visiting professor in the Master of Fine Arts Creative Writing and Literature Program at the State University of New York, Stony Brook. ${ }^{243}$ In the May 26, 2016 issue of The Atlantic, Mr. Gabler disclosed that he too would not be able to come up with $\$ 400$ to pay for an emergency without borrowing or selling something. ${ }^{244} \mathrm{Mr}$. Gabler describes himself this way:

I know what it is like to have to juggle creditors to make it through a week. I know what it is like to have to swallow my pride and constantly dun people to pay me so that I can pay others. I know what it is like to have liens slapped on me and to have my bank account levied by creditors. I know what it is like to be down to my last $\$ 5$-literally-while I wait for a paycheck to arrive, and I know what it is like to subsist for days on a diet of eggs. I know what it is like to dread going to the mailbox, because there will always be

\footnotetext{
${ }^{236} \mathrm{Id}$. at $166-67$. Fringe banking institutions are those that provide loans that conventional lenders will not because the loans are too small or too risky. Diane Hellwig, Note, Exposing the Loansharks in Sheep's Clothing: Why Re-Regulating the Consumer Credit Market Makes Economic Sense, 80 Notre Dame I. REv. 1567, 1567, 1569 (2005).

${ }^{237}$ "Unbanked" refers to persons who do not have a formal relationship with a bank. Baradaran, supra note 235 , at 166

${ }^{238}$ "Underbanked" refers to persons who may have a formal relationship with a bank, but who rely primarily on fringe banking institutions for their banking or credit needs. Id.

${ }^{239} \mathrm{Id}$.

${ }^{240}$ Report on the Economic Well-Being of U.S. Households in 2014. https://www.federalreserve.gov/ econresdata/2014-report-economic-well-being-us-households-201505.pdf (last visited May 14, 2016).

${ }^{241} I d$. at 18.

${ }^{242} I d$.

${ }^{243} \mathrm{http}: / /$ www.theatlantic.com/author/neal-gabler/ (last visited May 14, 2016).

${ }^{244}$ Neal Gabler, The Secret Shame of Middle-Class Americans: Nearly Half of Americans Would Have Trouble Finding $\$ 400$ to Pay for an Emergency. I'm One of Them, The Atlantic, May 26, 2016, http:// www.theatlantic.com/magazine/archive/2016/05/my-secret-shame/476415/ (last visited May 14, 2016).
} 
new bills to pay but seldom a check with which to pay them. I know what it is like to have to tell my daughter that I didn't know if I would be able to pay for her wedding; it all depended on whether something good happened. And I know what it is like to have to borrow money from my adult daughters because my wife and I ran out of heating oil.

You wouldn't know any of that to look at me. I like to think I appear reasonably prosperous. Nor would you know it to look at my résumé. I have had a passably good career as a writer-five books, hundreds of articles published, a num. ber of awards and fellowships, and a small (very small) but respectable reputation. You wouldn't even know it to look at my tax return. I am nowhere near rich, but I have typically made a solid middle- or even, at times, upper-middleclass income, which is about all a writer can expect, even a writer who also teaches and lectures and writes television scripts, as I do. ${ }^{245}$

He pointed out that financial advisers recommend that people save at least $10 \%$ to $15 \%$ of their income for retirement and emergencies, but he goes on to say that the reason many people cannot save for a "rainy day is that we live in an ongoing storm. Every day, it seems there is some, new, unantici. pated expense - a stove that won't light, a car that won't start, a dog that limps, a faucet that leaks. Four hundred dollar emergencies are not mere hy, potheticals, nor are $\$ 2,000$ emergencies. . The fact is that emergencies al. ways arise; they are an intrinsic part of our existences. . Life happens, yes, but shit happens too. . ..246

Mr. Gabler also discussed how income stagnation contributes to most Americans' perilous financial states. ${ }^{247} \mathrm{He}$ says that inflation adjusted wages "peaked in 1972, and since then, the average hourly wage has remained essen. tially flat." ${ }^{248} \mathrm{He}$ also says that "household incomes rose dramatically in the forty-seven years between 1967 and 2014 for the top quintile of income earn. ers, and even more dramatically for the top 5\%." 249 During that same period, however, "incomes in the middle quintile rose $23.2 \%$; incomes in the second lowest quintile rose $13.1 \%$; and incomes in the bottom quintile rose $17.8 \%$." 250 Income for the "bottom three quartiles peaked in 1999 and 2000, but since then, incomes in the middle quintile have declined by $6.9 \%$; incomes

\footnotetext{
${ }^{245}$ Gabler, supra note 244 , at 3 .

${ }^{246} \mathrm{Id}$. at 21 .

${ }^{247} \mathrm{Id}$. at 18 .

${ }^{248} I d$.

${ }^{249} \mathrm{Id}$. at 19 .

${ }^{250} \mathrm{Id}$. at 19 .
} 
in the second lowest quintile have declined by $10.8 \%$, and incomes in the lowest quintile have declined by $17.1 \%$."251

A report from May 2016 shows that the combined balances of a majority of Americans' checking and savings accounts is under $\$ 1,000$, which means most people in this country are a health incident or a car problem away from serious financial distress, ${ }^{252}$ and it is not true that the reason for this is because they spend too much money on frivolities. ${ }^{253}$ Again, Professor Warren's scholarship on this subject is compelling and insightful. ${ }^{254}$ In 2004, she published The Over-Consumption Myth and Other Tales of Economics, Law, and Morality.255

In The Over-Consumption Myth, Warren explains that "adjusted for inflation, a family of four today spends $21 \%$ less on clothing than it did in the early 1970s," which debunks the idea that people are in debt because they wasted their money on haute couture. ${ }^{256}$ She points out that "that same family of four does spend more eating at restaurants than it used to, but it spends a lot less at the grocery store because of bulk purchases and the availability of generic goods." 257 It would be a mistake, however, to conclude that families have the fiscal problems they do because they spend too much money at highpriced restaurants because even with the restaurant budget being what it is, "a four person family today spends $22 \%$ less on food than that same family did a generation ago." 258

Some attribute families' financial woes to overspending on luxury home goods like "dishwashers, washing machines, dryers, cable or satellite television, big screen televisions, and other consumer electronics." 259 Professor Warren rebuts this by observing that "these items were considered luxuries in 1970, but today, one can find one or more of them in over one-half of the homes in America." 260 Today, people of modest means who own consumer goods that were once the playthings of the rich are not auditioning for "Lifestyles of the Rich and Famous." ${ }^{261}$ Instead, they have these goods because they are more widely available and more affordable because the "costs of

\footnotetext{
${ }^{251} I d$.

${ }^{252}$ Robert Reich, The Jaw-Dropping Realities of Our Widening Economic Divide, Reader Supported News (May 3, 2016), http://readersupportednews.org/opinion2/277-75/36673-the-jaw-dropping-realities -of-our-widening-economic-divide (last visited May 16, 2016).

${ }^{253}$ Warren, supra note 17 , at $1492-1506$.

${ }^{254} \mathrm{Id}$.

${ }^{255}$ Warren, supra note 17 , at $1485-1511$.

${ }^{256} \mathrm{Id}$. at $1492-93$.

${ }^{257}$ Id. at $1493-94$.

${ }^{258} \mathrm{Id}$.

${ }^{259} \mathrm{Id}$. at $1494-95$.

${ }^{260} \mathrm{Id}$.

${ }^{261}$ This television series debuted in 1984 and each week highlighted the excesses of the "rich and famous," by focusing on "the prices the wealthy paid for luxuries like seaside villas, classic cars, and gold.
} 
manufacturing them has declined, and the goods last longer." ${ }^{262}$ Even with the proliferation of household appliances that were once the exclusive prov. ince of the affluent, such as microwave ovens, dishwashers, clothes dryers, and washing machines, "families spend $44 \%$ less on major appliances than they did a generation ago." ${ }^{263}$ As for vehicles, "in 2004, an average new car cost $\$ 22,000$, compared with $\$ 16,000$ in the late 1970s. ${ }^{264}$ Today's families pay more for new vehicles than their parents did, but they drive them for a longer period as evidenced by the fact that "the average family drives a car that is more than eight years old" and "a family of four spends $20 \%$ less on car payments, insurance, maintenance and the like than it did a generation ago." 265

So why then are so many people so broke? One answer is housing costs. ${ }^{266}$ According to Professor Warren, "in 2004, the median sale price for an existing home was $\$ 150,000$, which is $32 \%$ higher in inflation adjusted dollars from 1975, and housing costs consume more of a family's income than food, cars, health insurance, and child care." 267 Another reason why family budgets are so strained is the ever rising costs of healthcare. ${ }^{268}$ Professor Warren's work shows that "in 1972-1973, the average family of four spent $\$ 1,027$ on health insurance, but by the early 2000 s, that number increased to $\$ 1,650$."269 She also notes that "between 2000 and 2002, health insurance premiums increased by $28.4 \%$. ${ }^{270}$ In 2012, 1.1 million people filed for personal bankruptcy. ${ }^{271}$ As previously noted, the median average monthly income among these filers was $\$ 2,743$ per month, and their median average monthly expenses were $\$ 2,769$, a mere $\$ 26$ per month difference. ${ }^{272}$ The me-

plated bathroom fixtures." http://www.imdb.com/title/tt0086750/plotsummary?ref_=TT_ov_pl (last visited May 15, 2016).

${ }^{262}$ Warren, supra note 17 , at $1494-95$.

${ }^{263} I d$.

${ }^{264}$ Id. at $1499-1503$.

${ }^{265}$ Id. at 1500 .

${ }^{266}$ Id. at $1495-98$.

${ }^{267} I d$.

${ }^{268}$ Id. at $1498-99$.

${ }^{269} \mathrm{Id}$.

${ }^{270} I d$.

${ }^{271}$ Office of Inspector General, United States Postal Service, Providing Non-Bank Financial Services for the Underserved, at 14, (Jan. 27, 2014), https://www.uspsoig.gov/sites/default/files/document-library. files/2015/rarc-wp-14-007_0.pdf (last visited May 14, 2016); 2012 Report of Statistics Required by the Bankruptcy Abuse Prevention and Consumer Protection Act of 2005 (Dec. 31, 2012), at 5, 6, bttp:// www.uscourts.gov/statistics/table/all/bankruptcy-abuse-prevention-and-consumer-protection-act-bapcpa /2012/12/31 (last visited July 25, 2017).

${ }^{272}$ Office of Inspector General, United States Postal Service, Providing Non-Bank Financial Services for the Underserved, at 14, (Jan. 27, 2014), https://www.uspsoig.gov/sites/default/files/document-library. files/2015/rarc-wp-14-007_0.pdf (last visited May 14, 2016); 2012 Report of Statistics Required by the Bankruptcy Abuse Prevention and Consumer Protection Act of 2005 (Dec. 31, 2012), at 5, 6, http:// 
dian bankruptcy filer in 2012 was $\$ 26$ per month away from not having to file bankruptcy. ${ }^{273}$

It is indeed true that many people behave irresponsibly when it comes to spending. ${ }^{274}$ But it is a myth that the typical person who finds himself on the verge of financial collapse owes his plight solely or mostly to overconsumption. ${ }^{275}$ Professor Warren's work shows that "most American families spend less than they used to on ordinary consumption like consumer goods and more on the basics of being middle class like housing, healthcare, and transportation." ${ }^{276}$ It is no easy task to stay afloat financially. A person can be as morally upright as possible and still find himself in a financial tailspin as a result of the ordinary vicissitudes of everyday life. Such is the case for the overwhelming majority of persons who file bankruptcy. The bankruptcy system promises them a fresh start, and that promise is broken when a debtor is qualified for a job, the job can be performed successfully regardless of bankruptcy status, and an employer denies the person a job simply because of his or her bankruptcy status.

\section{CONCLUSION}

It is easy to heap calumny on debtors; after all, every debtor is a person who ultimately could not pay his or her bills, which means someone whom the debtor owed will not get paid anything or will get paid very little. Also, hiring a person to do any job entails some risk, and employers are right to be risk averse. Employers should not be irrational, however. One of the myths that persist about debtors is they are fiscal scofflaws who need to be shown tough love, and if that means they have a harder time getting hired, then so be it. The typical bankruptcy filer is not helped by being scorned or ridiculed by those fortunate enough to have steered clear of financial difficulty.

Employers should not deny employment to a person who is or has been a debtor if personal creditworthiness is not related to successful performance of the job the person seeks and the person is otherwise qualified. Some employers use bankruptcy status as a blunt instrument; if a person is or was a debtor, then he or she does not get the job, period, end of discussion. If an

\footnotetext{
www.uscourts.gov/statistics/table/all/bankruptcy-abuse-prevention-and-consumer-protection-actbapcpa/2012/12/31 (last visited July 25, 2017).

${ }^{273}$ Office of Inspector General, United States Postal Service, Providing Non-Bank Financial Services for the Underserved, at 14, (Jan. 27, 2014), https://www.uspsoig.gov/sites/default/files/document-libraryfiles/2015/rarc-wp-14-007_0.pdf (last visited May 14, 2016); 2012 Report of Statistics Required by the Bankruptcy Abuse Prevention and Consumer Protection Act of 2005 (Dec. 31, 2012), at 5, 6, bttp:// www.uscourts.gov/statistics/table/all/bankruptcy-abuse-prevention-and-consumer-protection-act-bapcpa /2012/12/31 (last visited July 25,2017 ).

${ }^{274} \mathrm{~W}$ arren, supra note 17 , at $1485-1495$.

${ }^{275} I d$.

${ }^{276}$ Id. at 1502 .
} 
employer is alarmed by what a bankruptcy might mean about an applicant's personal characteristics, it is not too much to ask for that employer to investigate a bit further to determine if the applicant actually lacks those characteristics. Relying on bankruptcy status simpliciter is antithetical to a core purpose of the bankruptcy system, which is to give debtors a fresh start. Employers' prerogatives to operate according to whatever employment policies and practices they wish should be balanced against employees' and potential employees' right to participate in the labor market in an environment free of irrational discrimination. It is irrational to deny employment to a person who is or was a debtor if the person is otherwise qualified, and the job can be successfully performed regardless of bankruptcy status. To allow such discrimination makes the bankruptcy system's promise of a fresh start illusory. 
